\title{
Review \\ Oxytocin Signaling as a Target to Block Social Defeat-Induced Increases in Drug Abuse Reward
}

\author{
Carmen Ferrer-Pérez ${ }^{1,+}+\mathbb{D}$, Marina D. Reguilón ${ }^{2,+} \mathbb{(}$, José Miñarro ${ }^{2}$ and Marta Rodríguez-Arias ${ }^{2, *}$ \\ 1 Department of Psychology and Sociology, University of Zaragoza, C/Ciudad Escolar s/n, 44003 Teruel, Spain; \\ c.ferrer@unizar.es \\ 2 Unit of Research Psychobiology of Drug Dependence, Department of Psychobiology, Facultad de Psicología, \\ Universitat de Valencia, Avda. Blasco Ibáñez, 21, 46010 Valencia, Spain; marina.reguilon@uv.es (M.D.R.); \\ jose.minarro@uv.es (J.M.) \\ * Correspondence: marta.rodriguez@uv.es \\ + Both authors equally contributed to the paper.
}

Citation: Ferrer-Pérez, C.; Reguilón, M.D.; Miñarro, J.; Rodríguez-Arias, M. Oxytocin Signaling as a Target to Block Social Defeat-Induced Increases in Drug Abuse Reward. Int. J. Mol. Sci. 2021, 22, 2372. https://doi.org/ $10.3390 /$ ijms 22052372

Academic Editor: Steven R. Laviolette

Received: 25 January 2021

Accepted: 23 February 2021

Published: 27 February 2021

Publisher's Note: MDPI stays neutral with regard to jurisdictional claims in published maps and institutional affiliations.

Copyright: (c) 2021 by the authors. Licensee MDPI, Basel, Switzerland. This article is an open access article distributed under the terms and conditions of the Creative Commons Attribution (CC BY) license (https:// creativecommons.org/licenses/by/ $4.0 /$ )
Abstract: There is huge scientific interest in the neuropeptide oxytocin (OXT) due to its putative capacity to modulate a wide spectrum of physiological and cognitive processes including motivation, learning, emotion, and the stress response. The present review seeks to increase the understanding of the role of OXT in an individual's vulnerability or resilience with regard to developing a substance use disorder. It places specific attention on the role of social stress as a risk factor of addiction, and explores the hypothesis that OXT constitutes a homeostatic response to stress that buffers against its negative impact. For this purpose, the review summarizes preclinical and clinical literature regarding the effects of OXT in different stages of the addiction cycle. The current literature affirms that a well-functioning oxytocinergic system has protective effects such as the modulation of the initial response to drugs of abuse, the attenuation of the development of dependence, the blunting of drug reinstatement and a general anti-stress effect. However, this system is dysregulated if there is continuous drug use or chronic exposure to stress. In this context, OXT is emerging as a promising pharmacotherapy to restore its natural beneficial effects in the organism and to help rebalance the functions of the addicted brain.

Keywords: oxytocin; drug addiction; social stress; corticotropin-releasing factor; reward system; animal models; human research; neuroinflammation

\section{Oxytocin as a Promising Therapeutic Treatment for Addiction Disorders 1.1. Endogenous Oxytocin (OTX) System}

There is huge scientific interest in the neuropeptide oxytocin (OXT) due to its putative capacity to modulate a wide spectrum of physiological and behavioral effects. It is mainly synthetized in the supraoptic nucleus (SON) and the paraventricular nucleus (PVN) of the hypothalamus, and the majority is released into the peripheral bloodstream through neurohypophysis [1]. In the periphery, OXT acts as a hormone that modulates parturition, lactation, and sexual stimulation, among other functions [2]. Within the central nervous system (CNS), oxytocinergic neurons project from the hypothalamus to a variety of brain regions such as the nucleus accumbens (NAc), prefrontal cortex (PFC), anterior olfactory nucleus, lateral septum (LS), bed nucleus of the stria terminalis (BNST), amygdala, and hippocampus [1].

The oxytocin receptor (OXTR) is a member of the rhodopsin-type $1 \mathrm{G}$ protein-coupled receptor family, and the expression of these receptors is believed to fluctuate in a sexdependent and species-specific manner [3]. These receptors are expressed in several tissues outside the CNS such as the heart, kidney, thymus, adipocyte tissue, gastrointestinal tract, mammary glands, and uterus [2]. Brain OXTRs are widely distributed and densely expressed in areas that are key to the regulation of social behavior, emotion, and motivation 
such as the mesolimbic circuit (including the PFC), NAc, and ventral tegmental area (VTA), among others $[2,3]$.

This vast distribution of OXTR illustrates how OXT modulates a wide array of physiological and cognitive processes [2,4]. Considering its potential to modulate motivation, learning, emotion, and the stress response, it is a crucial component to be taken into consideration when addressing an individual's vulnerability or resilience to developing a substance use disorder [5]. Moreover, the oxytocinergic system is reported to be altered after acute and chronic consumption of drugs of abuse, thus highlighting a possible use of exogenous OXT as a therapeutic tool in recovery from substance use disorders [6].

\subsection{Drug Exposure Alters Oxytocin Neurotransmission}

Clinical and preclinical studies suggest that oxytocinergic function in the brain is altered after acute or chronic exposure to drugs [6]. Preclinical studies show that acute exposure to psychostimulants such as cocaine can alter OXT levels in several brain areas. In a classic study, Johns, Caldwell, and Pedersen [7] found that two injections per day of $15 \mathrm{mg} / \mathrm{kg}$ cocaine over two days reduced hippocampal OXT in female rats, while no differences were observed in other structures such as the VTA or amygdala. Moreover, an up-regulation of OXTR in structures such as the piriform cortex, amygdala, NAc, and LS is usually observed after chronic psychostimulant administration in male rodents [8,9]. Interestingly, some studies have found that the dysfunction of the OXT system after psychostimulant administration can negatively affect several social and affiliative behaviors that are mediated by OXT such as pair bonding [10].

With respect to opiates, acute administration of morphine has been reported to reduce hypothalamic OXT release in lactating females [11], whereas other studies have found increased OXT immunoreactivity in the amygdala, hippocampus, and basal forebrain of male mice [12]. It has been hypothesized that these differential effects of acute opiate administration on OXT activity are dependent on the brain structure in question or the sex of the animal [13]. When considering the effects of chronic opioid administration over the OXT system, Zanos and collaborators $[13,14]$ described different examples of hypofunction such as reduced OXT synthesis, decreased OXT plasmatic levels, decreased OXT immunoreactivity in the hippocampus, and decreased OXT mRNA levels within the $\mathrm{SON}$, arcuate, and median eminence nucleus of the hypothalamus. As a consequence, a compensatory increase in OXTR binding has been observed in different brain areas such as the olfactory nuclei and the amygdala, which should be taken into consideration when deciding a possible OXT dose in subjects chronically exposed to opiates [13].

A similar pattern has been described regarding the effects of ethanol and $\Delta 9$ - tetrahydrocannabinol. After chronic ethanol administration, abstinent male rats exhibit decreased levels of OXT in the brain and increased levels of OXTR in frontal and striatal areas [15], while chronic exposure to $\Delta 9$-tetrahydrocannabinol downregulates OXT-NP mRNA expression in the VTA and NAc [16].

Clinical evidence of the impact of drug consumption on the OXT system is mainly derived from two types of studies: the analysis of plasmatic OXT levels in dependent and non-dependent subjects, and post-mortem studies. Broadly, clinical studies are in concordance with the aforementioned pre-clinical results, and confirm a similar dynamic change in the OXT system. For instance, acute alcohol consumption has been shown to decrease plasmatic OXT levels in women [17], while chronic exposure commonly produces a dysregulation of plasmatic OXT levels in men [18], in addition to neuroadaptations such as increases in OXTR mRNA and binding levels in frontal and striatal brain areas in post-mortem samples from alcohol-dependent male subjects [15].

To summarize, clinical and preclinical evidence suggests that repeated exposure to drugs leads to a drop in OXT levels that seems to be related to a decrease in its synthesis [19]. While the exact mechanism that drives the decrease of OXT synthesis is not fully understood [20], the consequences of this OXT hypofunction are better ascertained and have been related to compensatory changes that upregulate OXTR in different brain ar- 
eas $[9,20]$. These neuroadaptive changes in the endogenous OXT system mainly comprise brain regions involved in addiction and stress-related behaviors [6]. Discrepancies in the literature regarding the direction of OXT changes may be due to the brain region being analyzed [5] and the stage of the addictive cycle (acute administration, long-term dependence, or abstinence).

\subsection{OXT Modulates the Addictive Cycle}

The relationship between drugs of abuse and OXT is reciprocal. A vast body of scientific literature shows that, similar to the way drugs of abuse dysregulate the endogenous OXT system, OXT can modulate the individual's response to drugs. The therapeutic potential of OXT has been studied in all stages of the addiction cycle [21]. It has been shown to be protective in the initial stages of addiction as it diminishes behavioral and physiological responses to drugs. Preclinical evidence suggests that OXT prevents the progression from initial experimentation with a drug to dependence and escalation of drug-taking. Finally, OXT is a promising target in the management of drug abstinence and the rebalancing of brain functions after chronic exposure to drugs. In this section, we develop the hypothesis that this therapeutic potential is due to the way OXT modulates core neurobiological systems and processes that underlie the development of substance use disorders [21] (Figure 1).

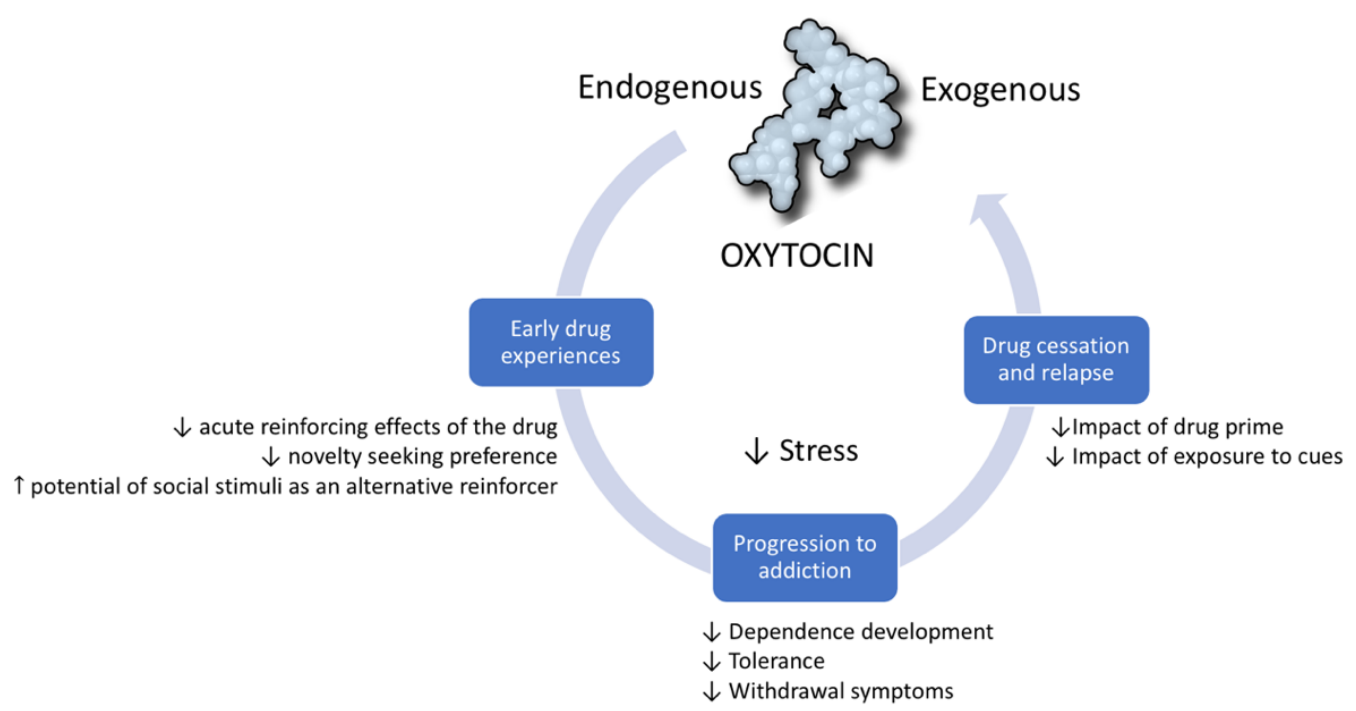

Figure 1. Oxytocin modulates the addiction cycle. Clinical and preclinical studies show that oxytocin has protective effects during all stages of the addiction cycle: (1) In early drug experiences, it diminishes the reinforcing and general effects of drugs. (2) It can prevent progression from initial drug experimentation to dependence and drug escalation. (3) In drug cessation, it can prevent relapse induced by cues, drug primes, and stress.

\subsubsection{OXT in Early Stages of Addiction}

During the early stages of addiction, drug taking is motivated mainly by the acute reinforcing effects of the drug [22]. The positive sensation or pleasure that is experienced is mediated by an increase in dopaminergic activity in the mesocorticolimbic system, which is also implicated in the development of neuroadaptations that underlie context-associated memories and the attachment to incentive salience to drug-related stimuli [22]. There is clear evidence that the neuropeptide OXT interacts with the reward system, and that the rewarding effects of pair bonding, sexual contact, and social interaction depend on the actions of OXT in the mesocorticolimbic circuit [23]. Additional evidence suggests that OXT is also able to interfere with the reinforcing effects of drugs of abuse, mainly through its modulatory effect on dopamine (DA) activity in key regions such as the NAc, VTA, and PFC [24]. 
OXT administration has been shown to reduce drug-induced increases in DA in different mesolimbic regions including the NAc [24,25]. For instance, Sarnyai and collaborators [26] found that OXT administration $(1 \mu \mathrm{g} / \mu \mathrm{L})$ directly into the NAc blocked cocaine-induced increases in DA release in male mice. Similarly, other studies with psychostimulants reported that intracerebroventricular $(2.5 \mu \mathrm{g} / \mu \mathrm{L})$ or peripheral $(1 \mathrm{mg} / \mathrm{kg})$ administration of OXT blocked methamphetamine-induced increases in DA activation in the NAc in male rodents $[27,28]$, an effect observed with other drugs such as alcohol. Peters and collaborators [25] found that intracerebroventricular administration of OXT $(1 \mu \mathrm{g} / 5 \mu \mathrm{L})$ blocked the increase of DA in the NAc shell after ethanol administration in naïve and chronically treated male rats, and attributed the subsequent decrease of ethanol consumption in a self-administration (SA) paradigm to this effect.

There is evidence that a positive social environment plus a well-developed endogenous OXT system is a protective factor that diminishes an individual's vulnerability to become initiated in the addictive cycle [29]. One of the mechanisms put forward to explain this effect is that OXT decreases novelty seeking and the initial response to drug reward [29,30]. Novelty seekers display a preference for novel environments and stimuli over familiar ones [31], and this behavioral trait has been linked to an increased risk of drug abuse in both humans and animal models [29,32]. For instance, rodent studies show that rats that display an enhanced locomotor response to a novel context also display an enhanced response to psychostimulant drugs and a faster acquisition of SA behavior [33]. Tops et al. [29] posited that an increased tone of endogenous OXT alters DA, serotonin, and endogenous opioid neurotransmission, thus promoting a shift in novelty processing from ventral to dorsal striatal structures and a subsequent decrease of preference and emotional reactivity to these contexts.

This protective effect of OXT in naïve animals during their first contacts with drugs has also been reported when OXT levels are acutely increased pharmacologically. For instance, the administration of intracerebroventricular OXT $(2.5 \mu \mathrm{g} / \mu \mathrm{L})$ to male mice prior to a methamphetamine conditioned place preference (CPP) protocol inhibited the acquisition of CPP for the context associated with the drug [34]. Moreover, repeated increases in OXT levels induced by pharmacological administration have been found to induce long-lasting neuroadaptive changes. In this regard, the repeated administration of OXT $(1 \mathrm{mg} / \mathrm{kg})$ during adolescence has been reported to decrease ethanol consumption and methamphetamine SA during adulthood in female and male rodents [35,36].

In addition, OXT has been shown to enhance the value of social stimuli, which in turn can act as an alternative reinforcer that changes the focus from drug reward to social reward [37]. For instance, Venniro and collaborators [38] found that in the presence of two possible rewards, social interaction versus the drug, rats that had developed methamphetamine SA behavior preferred the social reward. This effect has also been reported regarding the creation of drug-context-associated learning. For example, positive social interaction is rewarding enough to induce a strong conditioned preference [39] that can compete with the previously established conditioned preference for cocaine [40].

\subsubsection{OXT in the Progression to Addiction}

OXT also has the potential to prevent the progression of the addictive cycle by stemming the development of dependence and the appearance of behavioral alterations after continuous contact with the drug [6,20]. The initial motivation to consume a drug is first driven by positive reward experiences; however, after repeated drug consumption, there is a shift of motivation to avoid the negative emotional state that emerges during abstinence [22].

Dependence is a state in which drug users display neuroadaptive alterations within the reward system and in other brain structures such as those implicated in the stress response [22]. OXT has been found to attenuate the development of tolerance and dependence, and this effect has also been related to its potential to modulate DA neurotransmission in the mesocorticolimbic circuit [41]. In this regard, endogenous OXT attenuates 
the development of tolerance to the analgesic effects of opiates, a phenomenon that has been demonstrated by intracerebroventricular administration of selective OXT antagonists to tolerant male mice, which induces a further decrease in the analgesic effect of morphine $[42,43]$. OXT ( 5 or $0.5 \mu \mathrm{g}$ ) also reduces tolerance to the sedative and hypothermic effects of ethanol [44] and modulates psychostimulant-induced stereotypy and locomotor sensitization [45]. Based on its potential to prevent the development of tolerance, it has been posited that OXT exerts a general attenuation of the neuroadaptations that underlie drug addiction $[41,46]$.

Finally, it has been demonstrated that OXT is useful in the management of long- and short-term abstinence [21]. During abstinence, individuals generally experience negative somatic symptomatology, hypohedonia (reduced response to natural reward), stress, and anxiety, all of which drive drug seeking and consumption to relieve this negative emotional state [22]. An exhaustive description of the neurobiological mechanism that sustains the so-called "dark side of addiction" can be found in Koob and Volkow [22]. In short, this negative affect stage is the result of hypodopaminergic activity in the reward system, while there is hyperactivity in the brain stress system and hypothalamic-pituitary-adrenal (HPA) axis. Clinical and preclinical studies show that acute OXT administration can decrease both somatic and motivational symptoms of withdrawal from different drugs of abuse [21]. Generally, preclinical studies show that OXT can decrease withdrawal symptoms such as facial fasciculations, convulsion, hypothermia, and anxiety-like and depression-like behavior during morphine, cocaine, nicotine, and alcohol abstinence (an exhaustive review can be found in Bowen and Neumann [21]). For instance, when Szabó and co-workers [47] injected different doses of OXT $(0.02,0.2$, and $2 \mathrm{IU})$ to alcohol-dependent male mice, they found that withdrawal convulsions decreased in a dose-dependent manner. This potential of OXT to decrease alcohol withdrawal has also been tested in a small sample of humans in a double-blind placebo-controlled trial, with positive results. Pedersen and collaborators [48] administered intranasal OXT (24 IU) twice daily for three days to alcohol-dependent patients admitted for medical detoxification. Their results showed that OXT-treated patients self-reported less severe withdrawal symptoms including craving, and required less lorazepam during their detoxification treatment. Similarly promising results have been obtained in other clinical trials with different drugs of abuse. For example, Stauffer and collaborators [49] found that intranasal OXT administration (40 IU) decreased cocaine and heroin craving in patients in methadone maintenance treatment. However, although preclinical studies provide strong evidence that OXT decreases withdrawal symptoms, clinical studies of OTX are still at an early stage, and mixed results have been reported [41].

\subsubsection{OXT in the Prevention of Reinstatement and Relapse into Drug Use}

Three classic triggers provoke relapse into drug seeking: exposure to drug cues, drug priming, and stressful experiences. Preclinical studies highlight the potential of OXT to impede the activation of the NAc by these factors, therefore decreasing its potential to promote a reinstatement of drug seeking behavior [21]. In this regard, Cox and collaborators $[50,51]$ found that peripheral administration of OXT $(1 \mathrm{mg} / \mathrm{kg})$ prior to drug-paired cues, pharmacological stress, or drug-priming decreased the reinstatement of drug seeking in female and male rats in a methamphetamine SA paradigm.

In human studies, a single acute dose of intranasal OTX (20 IU) has been shown to reduce the craving for tobacco induced by cues in abstinent smokers of both sexes [52], though it has been reported not to diminish the craving for tobacco induced by social stress with a high dose (40 IU) $[53,54]$. OXT produces mixed effects with regard to modulating craving of cannabis, which may be determined by the level of dependence; for instance, it was shown to decrease craving induced by social stress in dependent individuals [55], while no effects were observed in recreational users [56].

The anti-stress effect of OXT may be one of the mechanisms underlying its therapeutic potential. Stress is considered to be a risk factor in all stages of the addictive process, first by 
increasing vulnerability to drug experimentation, then by enhancing the risk of developing dependence, and finally by provoking relapse during drug cessation [57]. Additionally, physical and social stress has been demonstrated to prime the immune system into a proinflammatory state, which in turn has been shown to modulate vulnerability to develop several health problems including drug addiction [58]. OXT has anti-stress and antiinflammatory effects, and also enhances the stress-buffering effects of other interventions such as social support [59-61]. This effect can be explained broadly due to its potential to decrease the reactivity of the HPA axis by reducing the release of adrenocorticotropic hormone (ACTH) and corticotropin-releasing factor (CRF) [1]. The importance of OXT as an anti-stress intervention is a crucial development that will be discussed in the following sections of this review.

\section{The Anti-Stress Potential of Oxytocin}

\subsection{What Is Social Stress?}

Selye [62] defined stress as a non-specific biological response of the body to a demand made on it from the outside (the environment). It is a normal adaptive response in which the body's reserves are mobilized [63,64]. In today's society, the main stressors that people suffer are of a social nature (social organization, social support, socioeconomic aspects, scholar life, marital status, work role, gender, discrimination, etc.). Social stress can be defined as the breakdown of the organism's homeostasis due to neurophysiological changes derived from social and environmental events or circumstances related to the individual [65-67]. Inevitably, socially stressful events are part of the daily life of human beings. Sometimes these are specific events that generate a high stress response but involve a rapid recovery of homeostasis; on other occasions, the event lasts longer than the individual wishes $[68,69]$. When the breakdown of homeostasis is prolonged over time due to stress, there is an imbalance in the correct functioning of various brain and hormonal systems that can eventually lead to a series of diseases. Indeed, clinical and preclinical studies have demonstrated that social stress is a fundamental factor in the development of various mental disorders such as depression, anxiety disorders, neurodegenerative disorders, and addiction [70-76].

Studying and understanding the brain mechanisms involved in the impact of social stress on the organism is a complex issue. Animal models allow us to represent the experiences and social conditions that induce psychosocial stress in humans. In recent decades, they have facilitated an enormous expansion of our knowledge concerning social stress and the mechanisms it triggers in the stress system and other systems (such as the immune system) as well as its relationship with a large number of mental disorders. Social defeat (SD) involves an agonistic encounter between conspecifics and mimics a subordinate vs. outsider scenario in human relations [77,78]. It is considered the most representative animal model for studying social stress due to its high translational value and ecological and ethological validity [78-80]. The SD model consists of various agonistic encounters during which an experimental animal (intruder) is introduced into the home cage of an animal that has experienced prolonged isolation (resident), so that the resident threatens and attacks the intruder in an expression of territorial dominance [81,82]. One of the disadvantages of SD is that it is designed only for males, as female rodents are not territorial and do not engage in aggressive behavior (except under specific circumstances) and are, therefore, not sufficiently aggressive to be subject to defeat-induced stress $[83,84]$. To study social stress in females, alternative models are employed such as social instability or vicarious social defeat $[85,86]$.

\subsection{Brain Mechanisms Activated by Social Stress}

The adaptive response of our body to a stressor is expressed by the activation of the HPA axis. The processing of the information of the stressor takes place in the PVN of the hypothalamus. Nerve signals promote the synthesis of CRF and other peptides such as vasopressin and OXT, which are released from the PVN, from where they are conducted 
to the anterior pituitary $[87,88]$. Once the CRF reaches the anterior pituitary, it stimulates the synthesis and release of another hormone, ACTH. This hormone is then secreted by the anterior pituitary and travels through the circulatory system until it reaches the adrenal glands, where glucocorticoids (GC) (cortisol or corticosterone) and catecholamines (adrenaline and noradrenaline) are secreted [89]. Cortisol acts in close liaison with the autonomic nervous system in such a way that if cortisol levels increase due to the effects of stress, heart rate and blood pressure also rise [90]. Moreover, GC regulate the inflammatory response through both direct transcriptional action on target genes and indirect inhibition of the transcriptional activity of transcriptional factors [91,92]. The direct transcriptional action of GC influences the induction of the synthesis of anti-inflammatory proteins such as lipocortin 1, IL-10, SLP1, or the antagonist of IL-1 receptors through the binding of GC receptors to GC response elements of DNA found in the promoter region of the target genes [93-95]. Indirectly, the GC receptor interacts with transcription factors such as AP-1 or NF-kB, preventing them from binding to DNA and exerting the corresponding gene regulation [93,94]. Moreover, GC receptors bind to coactivating molecules such as cAMP response element-binding protein (CREB)-binding protein (CBP) or $\mathrm{p} 300$, inhibiting the intrinsic activity of histone acetyltransferase (HAT) and recruiting histone deacetylases (HDAC), which promotes folding of DNA around histones. As a consequence, the transcription of pro-inflammatory proteins such as TNF $\alpha$, IL-1 $\beta$, IL-12, IFN- $\gamma$, IL-6, MIP- $1 \alpha$, MCP-1, or COX-2 is inhibited [96,97].

The HPA axis is capable of self-regulating; when blood levels of GC are high, a negative feedback is produced in the GC receptors of the hypothalamus and PVN, thereby inhibiting their secretion. This occurs due to the negative response of GC in the CRF promoter, which inhibits the binding of the transcriptional machinery to the CRF promoter, reducing the transcription of the CRF gene [98].

When this negative feedback fails, the continued activation of CRF causes a series of neuroadaptations that affect the neurotransmitter and immune systems [79]. After repeated exposure to SD, the extra-hypothalamic release of CRF activates the mesocorticolimbic DA system [99]. This activation of the dopaminergic system produces a decrease in social interaction in animals as well as depressive-like symptoms and anhedonia, amongst other effects $[100,101]$. The serotonin and norepinephrine systems constitute other signaling systems involved in a series of mental disorders (anxiety, depression, etc.) and are also affected by social stress [102-105]. Chronic social stress produces an upregulation of the serotonin transporter in the dorsal raphe nucleus, which translates into a deficiency of synaptic serotonin, thus contributing to the appearance of depressive symptoms that can promote the addictive process $[79,106,107]$. In addition, activation of the HPA axis increases the release of norepinephrine, and if this increase is prolonged, it can produce negative emotions such as anxiety and fear [108].

Prolonged exposure to social stress produces a desensitization of GC receptors [74, 109,110], thus reducing the effectiveness of GCs in inhibiting transcription factors (e.g., NF-kB) and the intrinsic activity of HAT. Research suggests that chronic or prolonged social stress leads to overactivation of the immune system as a result of less suppressive effects of GC on transcription factors, and enhances expression of pro-inflammatory signals in peripheral monocytes, thus increasing inflammatory signaling [74,111-113].

Finally, we must mention another important effect induced by social stress; namely, the alteration of the signaling of the neuropeptide OXT. The release of OXT from the PVN has the ability to inhibit or dampen the response of the HPA axis [114,115]. As abovementioned, OXT is synthesized by two types of neurons: parvocellular and magnocellular neurons. The main outputs of these projections feed the CRF neurons of the PVN. OXT exerts its role in the adaptive response to social stress by diminishing the stress response through the regulation of CRF. A more in-depth explanation of this modulation can be found in the next section. 


\subsection{Role of Oxytocin in Social Stress}

OXT plays an important role in CRF transcription. Activation of the OXTR in the PVN interferes with the expression of $\mathrm{CRF}$, and binds and sequesters the coactivator of the CRF transcription factor CREB (CRTC3). In this way, OXT reduces the binding of CRTC3 to the promoter of the CRF gene and delays its expression [116]. In this way, OXT is a stress modulator induced by activation of the HPA axis [117-119].

Studies in animal models and humans demonstrate this modulating effect, illustrating a reduction in the secretion of GC (cortisol and corticosterone) induced by the secretion of OXT after exposure to acute social stress [60,120-123]. In an interesting experiment, Engert and co-workers [124] observed peripheral OXT secretion in response to acute social stress (Trier Social Stress Test) in healthy humans. First, the authors associated enhanced peripheral OXT secretion with higher overall cortisol reactivity during the reactivity phase in response to psychosocial stress. Later, during the recovery phase, a greater secretion of OXT was paralleled by a more rapid recovery of vagal activity. Thus, it would appear that higher OXT plasmatic levels reduce stress reactivity faster after the stressor has ceased to be present [124-126].

In contrast, the consensus in the scientific literature is that when exposure to social stress is prolonged or chronic, there is a dysfunction of endogenous OXT characterized by sexual differences. Litvin and co-workers [127] reported that male mice undergoing chronic SD showed an increase in the OXTR of the medial amygdala (MeA) and LS, and hypothesized that it was involved in the negative social behaviors induced by SD. Likewise, an increase in the expression of the c-Fos protein has been observed in the OXT neurons of BNST, SON, PVN, and in the OXTRs of male mice exposed to SD [128]. Other studies have reported similar alterations in female rodents subjected to SD or social instability; for example, Steinman and co-workers $[129,130]$ observed a long-lasting increase in OXT production and OXT/c-fos cells in the medioventral BNST and rostral PVN of female California mice, but not in their male counterparts. Hyperactivity of medioventral BNST and PVN OXT neurons in turn increases OXTR activation in the anteromedial BNST, inducing avoidance of unknown social contexts among female California mice $[129,131]$. Other studies have obtained contrasting results; for example, in an experiment using the chronic social instability paradigm, OXTRs were observed to be significantly increased in the amygdala and decreased in the PFC and hypothalamus of female rats [132]. Equally, female mandarin voles show a decrease in the number of OXT projections and a decrease in expression levels of proteins and mRNA of OXTR in the NAc shell after chronic SD [133].

Studies in humans have shown that people with major depression disorder (MDD) faced with a social exclusion task exhibit lower plasmatic levels of OXT than controls [134], which produces an increase in negative emotions in these circumstances. This can be interpreted as an endogenous deficit that leads to isolation and personal failure [135], or alternatively, as a protective mechanism against social stress by which lower levels of OXT regulate aversive social cues so that social stress stimuli are experienced as less aversive [136]. Gender differences have also been described, since women with chronic depression and MDD show lower plasma levels of OXT than males [134,135]. Decreased plasma levels of OXT have also been observed in patients with social anxiety disorder [137], which could reflect a lower ability to react pro-socially [138].

To summarize, both animal models and human studies have revealed unquestionable discrepancies concerning the effects of social stress on endogenous OXT that involve sex differences. It should be noted that testosterone can reduce the activity of the HPA axis, while it has been shown that estrogens can increase or reduce the activity of this axis according to the differential activity on the estrogen $\alpha$ (increased activity of the HPA axis) and $\beta$ (decreased HPA axis activity) receptors [2,121,132]. We can conclude that social stress modifies the projection of OXT neurons and alters plasmatic levels of OXT in both humans and animals. These changes produce a dysfunctionality in the main role of OXT in stress, which is the modulation of the HPA response and reduction of the impact of the stress response. 


\subsection{Exogenous OXT Administration as a Therapeutic Target for Social Stress Disorders}

Based on the above-mentioned results, a large number of studies have been carried out to explore the administration of OXT as an agent for treating depressive or anxiogenic mood states derived from social stress exposure. These studies have also highlighted important discrepancies, due perhaps to varying forms of administration and doses employed and gender differences. For example, Eckstein and colleagues [136] observed that healthy men who received intranasal OXT (24 IU) before social stress (The Montreal Imaging Stress Task) did not show increases in cortisol levels in saliva, but did manifest an increase in perceived social stress. In contrast, Heinrichs and co-workers [60] reported the opposite, registering protective effects in healthy men who received the same intranasal dose of OXT before the Trier Social Stress Test. In said studies, the subjects did not display alterations in the HPA or the OXT system as a result of prolonged or continuous exposure to social stress. Other studies have been conducted in patients with a history of depression, anxiety disorders, or prolonged exposition to social stress during childhood. In male patients with generalized anxiety disorder, intranasal administration of OXT (24 IU) normalized the decreased connectivity of the frontal-amygdala (left and right amygdala with rostral anterior cingulate cortex/medial PFC (mPFC) connectivity) that usually occurred in these subjects during the emotional face processing task [139-142]. Additionally, these patients showed increased empathy after receiving intranasal OXT (24 IU) in a reward motivation task [143]. The benefits of treatment with OXT have also been observed in male subjects who have experienced early adverse experiences, in whom improvements were observed in the connectivity between the amygdala and the PFC [144] and in the ability to face emotion recognition [145]. In a more recent study, the efficacy of intranasal OXT (24 IU) in improving the recognition of emotions has also been demonstrated in healthy adults of both sexes [146]. Additionally, in a series of studies carried out in male and female police officers with post-traumatic stress disorder, intranasal administration of higher doses of OXT (40 IU) improved motivation tasks and social reinforcement. Likewise, through functional magnetic resonance imaging (fMRI), an increase in neural responses was observed in the striatum, dorsal anterior cingulate cortex [147], and insula [147,148] with respect to patients treated with a placebo. Several studies by Koch and co-workers suggest that OXT acts as a cognitive regulator of emotions and anxiety; for instance, it decreased anxiety before an emotional faces recognition task and lowered the reactivity of the amygdala during the task [149]. In an extension of the study in question, an increase in connectivity between the left thalamus and amygdala was observed during a distraction task in male patients [150].

Similarly, preclinical research has revealed that injections of OXT (1 ng/200 nL) into the NAc shell reverses the alterations in social behavior, anxiety, and depressive symptoms induced by chronic SD, while injections of an antagonist blocks the effects of OXT in female mandarin voles $[133,151]$. Local administration of OXT $(1 \mathrm{or} 5 \mu \mathrm{g})$ to the PFC of male mice can reduce depressive-like symptoms in defeated mice, with a subsequent increase in DA levels taking place. Moreover, OXT increases phosphorylation of protein kinase A (PKA) and dopamine and cAMP-regulated phosphoprotein of $32 \mathrm{kDa}$ (DARPP-32) in intracellular PKA/DARPP-32 signaling dependent on D1 receptor activation. Thus, the enhancement of dopaminergic transmission induced by administration of OXT reduces the depressive symptoms produced by SD in the MPFC [152].

\section{Oxytocin Blocks Increased Drug Intake Induced by Social Defeat}

SD stress induces long-lasting changes in the reward system that affect the response to drugs of abuse such as cocaine or ethanol. After SD, increases in the acquisition of and motivation to take cocaine has been extensively reported using the SA procedure [153156]. Equally, defeated mice show higher ethanol intake in the oral SA paradigm [61, $76,157,158]$. Studies using the CPP paradigm have also shown an enhancement in the conditioned rewarding effects of cocaine and ethanol in stressed animals [73,158-161]. Both 
the aforementioned paradigms permit a broad assessment of the rewarding effects of drugs of abuse as both measure the role of motivation and environmental cues [162,163].

Repeated social stress and prolonged substance use induce long-lasting changes in the reward system that influence both processes mutually, since a state of chronic stress will produce neuroadaptations that promote the development of the addictive spiral, and vice versa $[164,165]$. Together, OXT and DA play a crucial role in the reward system; DA in the reward system areas, VTA and NAc are negatively affected by exposure to continuous stress and by continued consumption of substances of abuse, both of which decrease DA [161,166168]. As previously mentioned, OXT is released as an adaptive factor in the face of acute stress, but its synthesis can be impaired when stress is prolonged $[115,169]$. Additionally, after prolonged drug use, the OXT system induces neuroadaptive changes in areas involved in the reward system (VTA, NAc) that produce an upregulation of OXTR $[6,9,19,20,170]$. Moreover, OXTRs are expressed by non-dopaminergic neurons in the VTA such as GABA and glutamate neurons, which can modulate the activity of these DA VTA neurons locally (in opposite directions) or project to other brain regions including the NAc where they can alter the positive reinforcement or aversion produced by substances of abuse [171-173].

Taking into account the scientific evidence presented so far, OXT is a promising therapeutic target that reverses the effects of social stress (Table 1). With the aim of testing this therapeutic potential, our research team has conducted various studies to explore the role of OXT in relation with social stress and addictive behavior. First, we evaluated social housing conditions as a possible protective factor against the negative effects induced by SD such as the increased rewarding effects of cocaine or anxiety-like behaviors. Stressed mice were housed in five different conditions: standard housing (four males in each cage); two males in a cage from adolescence or starting in adulthood; and one adult male housed with a female for a short or long period. Male mice that had lived in an environment with quality social attachments (paired with a female) or with another male from adolescence onwards displayed a resilient profile after social stress experiences, with decreased response to cocaine reward and less anxiolytic responses [174]. This protective effect correlated with increased plasmatic OXT levels in the mice housed with a female. Although levels also increased in defeated males paired with another male from adolescence onwards, they did not reach the levels observed in those paired with a female. However, blockade of endogenous OXT using the OXTR antagonist atosiban $(1 \mathrm{mg} / \mathrm{kg})$ completely annulled the protective effect of housing conditions in the case of the co-housed males, thus highlighting a critical role for OXT [175].

If favorable social housing can avoid the increase in the rewarding effects of cocaine induced by SD through an increment of OXT, we predicted that the same results could be obtained if we administered exogenous OXT to animals housed under standard conditions. To test this hypothesis, we administered, peripherally, one dose of OXT $(1 \mathrm{mg} / \mathrm{kg})$ before each agonistic encounter. In relation to cocaine, our results showed that the administration of OXT before each SD blocked the long-term increase in the conditioned rewarding effects of cocaine and cocaine SA induced by SD. We also observed that OXT was capable of undermining the reinstatement of cocaine-seeking behavior in the latter paradigm. In addition, OXT administration prior to each SD decreased anxiety-like behaviors [59].

Finally, we set out to test if this beneficial effect of OXT could also be applied to the increased ethanol intake observed in socially stressed mice. Our results confirmed that peripheral administration of OXT $(1 \mathrm{mg} / \mathrm{kg})$ before each SD reversed the long-term negative effects of SD on ethanol consumption [61]. OXT-treated stressed animals consumed similar amounts of ethanol to the control group and showed less motivation to obtain the drug compared to untreated defeated animals in the oral ethanol SA paradigm. 
Table 1. Effect of the administration of oxytocin as a therapeutic target in the addictive process induced by social stress in animal models and clinical studies.

\begin{tabular}{|c|c|c|c|c|c|}
\hline Species & Stress Type & $\begin{array}{l}\text { Paradigm/Drug } \\
\text { Disorder }\end{array}$ & Treatment/Dosage & Finding & Reference \\
\hline Male mice & Social Defeat & $\begin{array}{l}\text { Cocaine CPP } \\
\text { Cocaine SA }\end{array}$ & $\begin{array}{l}\text { Oxytocin } \\
1 \mathrm{mg} / \mathrm{kg} ; \text { i.p. }\end{array}$ & $\begin{array}{l}\text { Blocked the long-term increase in the } \\
\text { conditioned rewarding effects, favored } \\
\text { extinction and decreased reinstatment }\end{array}$ & 59 \\
\hline Male mice & Social Defeat & Ethanol SA & $\begin{array}{c}\text { Oxytocin } \\
1 \mathrm{mg} / \mathrm{kg} ; \text { i.p. }\end{array}$ & $\begin{array}{l}\text { Blocked the long-term increase ethanol } \\
\text { consumption and seeking behavior }\end{array}$ & 61 \\
\hline $\begin{array}{l}\text { Male and female } \\
\text { mice }\end{array}$ & Predator odor & Ethanol SA & $\begin{array}{l}\text { Oxytocin } \\
1 \mathrm{mg} / \mathrm{kg} ; \text { i.p. }\end{array}$ & Attenuated alcohol seeking behavior & 176 \\
\hline Male mice & Restraint & $\begin{array}{l}\text { Methamphetamine } \\
\text { CPP }\end{array}$ & $\begin{array}{l}\text { Oxytocin } \\
0.1,0.5,2.5 \mu \mathrm{g} / \mu \mathrm{l} ; \\
\text { i.c.v. }\end{array}$ & Attenuated reinstatment & 34 \\
\hline Male mice & Forced swimming stress & $\begin{array}{l}\text { Morphine } \\
\text { CPP }\end{array}$ & $\begin{array}{l}\text { Carbetocin * } \\
6.4 \mathrm{mg} / \mathrm{kg} ; \text { i.p. }\end{array}$ & Attenuatted reinstatment & 14 \\
\hline Male rats & Predator odor & $\begin{array}{l}\text { Methamphetamine } \\
\text { CPP }\end{array}$ & $\begin{array}{l}\text { Oxytocin } \\
1 \mathrm{mg} / \mathrm{kg} ; \text { i.p. }\end{array}$ & Decreased CPP acquisition & 177 \\
\hline $\begin{array}{l}\text { Male and female } \\
\text { rats }\end{array}$ & Yohimbine & $\begin{array}{l}\text { Methamphetamine } \\
\text { CPP }\end{array}$ & $\begin{array}{l}\text { Oxytocin } \\
1 \mathrm{mg} / \mathrm{kg} ; \text { i.p. }\end{array}$ & Decreased CPP acquisition & 50 \\
\hline $\begin{array}{l}\text { Male and female } \\
\text { humans }\end{array}$ & $\begin{array}{l}\text { Mistreatment during } \\
\text { childhood }\end{array}$ & Cocaine-dependent & $\begin{array}{l}\text { Oxytocin } \\
40 \mathrm{IU} \\
\text { intransal }\end{array}$ & Reduced risk of relapse & 178 \\
\hline $\begin{array}{l}\text { Male military } \\
\text { veterans humans }\end{array}$ & $\begin{array}{l}\text { Post-traumatic stress } \\
\text { disorder }\end{array}$ & $\begin{array}{l}\text { Alcohol use } \\
\text { disorder }\end{array}$ & $\begin{array}{l}\text { Oxytocin } \\
40 \mathrm{IU} ; \\
\text { intransal }\end{array}$ & $\begin{array}{l}\text { Attenuated reactivity of cortisol to stress task, } \\
\text { but did not reduce craving }\end{array}$ & 179 \\
\hline $\begin{array}{l}\text { Male and female } \\
\text { humans }\end{array}$ & $\begin{array}{l}\text { Adverse experiences in } \\
\text { childhood }\end{array}$ & Tobacco smokers & $\begin{array}{l}\text { Oxytocin } \\
40 \mathrm{IU} ; \\
\text { intransal }\end{array}$ & $\begin{array}{l}\text { Attenuated cortisol response in trier social } \\
\text { stress task. Greater anxiolytic effect in men }\end{array}$ & 180 \\
\hline
\end{tabular}

* Carbetocin is a synthetic analog of oxytocin.

Other groups have evaluated the protective role of OXT against relapses into the consumption of different drugs of abuse as a result of social stress. OXT $(1 \mathrm{mg} / \mathrm{kg})$ attenuated alcohol-seeking behavior in a dose-related manner in male and female mice in response to an acute challenge with a predatory odor [176]. Similar results have been observed in the tempering of drug seeking and reinstatement due to different types of stress. For example, intracerebroventricular OXT $(0.1,0.5,2.5 \mu \mathrm{g} / \mu \mathrm{L})$ attenuated the reinstatement of restraint stress-induced methamphetamine CPP [34], and systemic administration of $6.4 \mathrm{mg} / \mathrm{kg}$ of carbetocin (OXT analog) reduced the effects of forced swimming stress on CPP reinstatement induced by morphine [14] in male mice. Furthermore, systemic administration of OXT $(1 \mathrm{mg} / \mathrm{kg})$ decreased methamphetamine-seeking behavior after exposure to a predator's odor [177] and administration of yohimbine in rats [50]. In humans, intranasal OXT (40 IU) may be beneficial in reducing the risk of relapse among cocainedependent individuals (both sexes) with a history of mistreatment during childhood [178]. Another study in male military veterans with post-traumatic stress and alcohol use disorder revealed that intranasal administration of OXT (40 IU) attenuated the reactivity of cortisol to stress tasks, though it did not mitigate craving [179]. In adult tobacco smokers who have suffered adverse experiences in childhood, intranasal administration of OXT (40 IU) prior to the Trier Social Stress Task has been shown to attenuate cortisol response in both sexes. However, this reduction in cortisol was larger in men with greater childhood adversity, pointing to a greater benefit from the anxiolytic properties of OXT in this sex [180].

Several mechanisms could explain the above-mentioned beneficial effect of OXT. One factor to take into account is that OXT can modulate the neuroinflammation induced by SD (Figure 2). Numerous reports confirm that social stress induces a potent and long-lasting neuroinflammatory response [181-184]. Neuroinflammation is composed of a series of cellular (affecting mainly microglia) and molecular (increased release of cytokines and chemokines) alterations in the form of an immune response within the CNS. Neuroinflammation is not only provoked by pathological conditions, but is also trigged by psychological stress (see review [182]). SD-induced neuroinflammation provokes increases in macrophages and activated microglia in the brain [185], thus increasing pro-inflammatory cytokines and chemokines (as IL-1 $\beta$, IL-6 or CX3CL1) $[61,157,159,174,186]$. In addition, exposure to SD augments the permeability of the blood-brain barrier, allowing immune 
cells to cross into the CNS [183]. OXT is reported to inhibit pro-inflammatory mediators such as TNF- $\alpha$, IL-1 $\beta$, and nitric oxide synthase [187-189]. We have recently confirmed these effects when we observed that peripheral OXT $(1 \mathrm{mg} / \mathrm{kg})$ administration mitigated the neuroinflammatory response induced in male mice by repeated SD. These OXT-treated animals displayed neuroinflammatory levels of chemokines (CX3CL1 and CXCL12) that were lower than those observed in non-treated defeated mice [61]. Similar results have been obtained with other types of social stress. For example, intracerebroventricular administration of OXT $(1 \mu \mathrm{g} / \mu \mathrm{L})$ in adult male mice subjected to maternal separation mitigated the increase in the expression of genes relevant to the neuroinflammatory response (IL$1 \beta$, Myd88, TNF- $\alpha$, TLR4, and Nlrp3) [190]. Moreover, intranasal administration of OXT $(1 \mu \mathrm{g} / \mu \mathrm{L})$ to male rats reversed the increase in IL-1 $\beta$ and IFN- $\gamma$ levels in the mPFC and hippocampus induced by a rodent model of posttraumatic stress disorder [191].

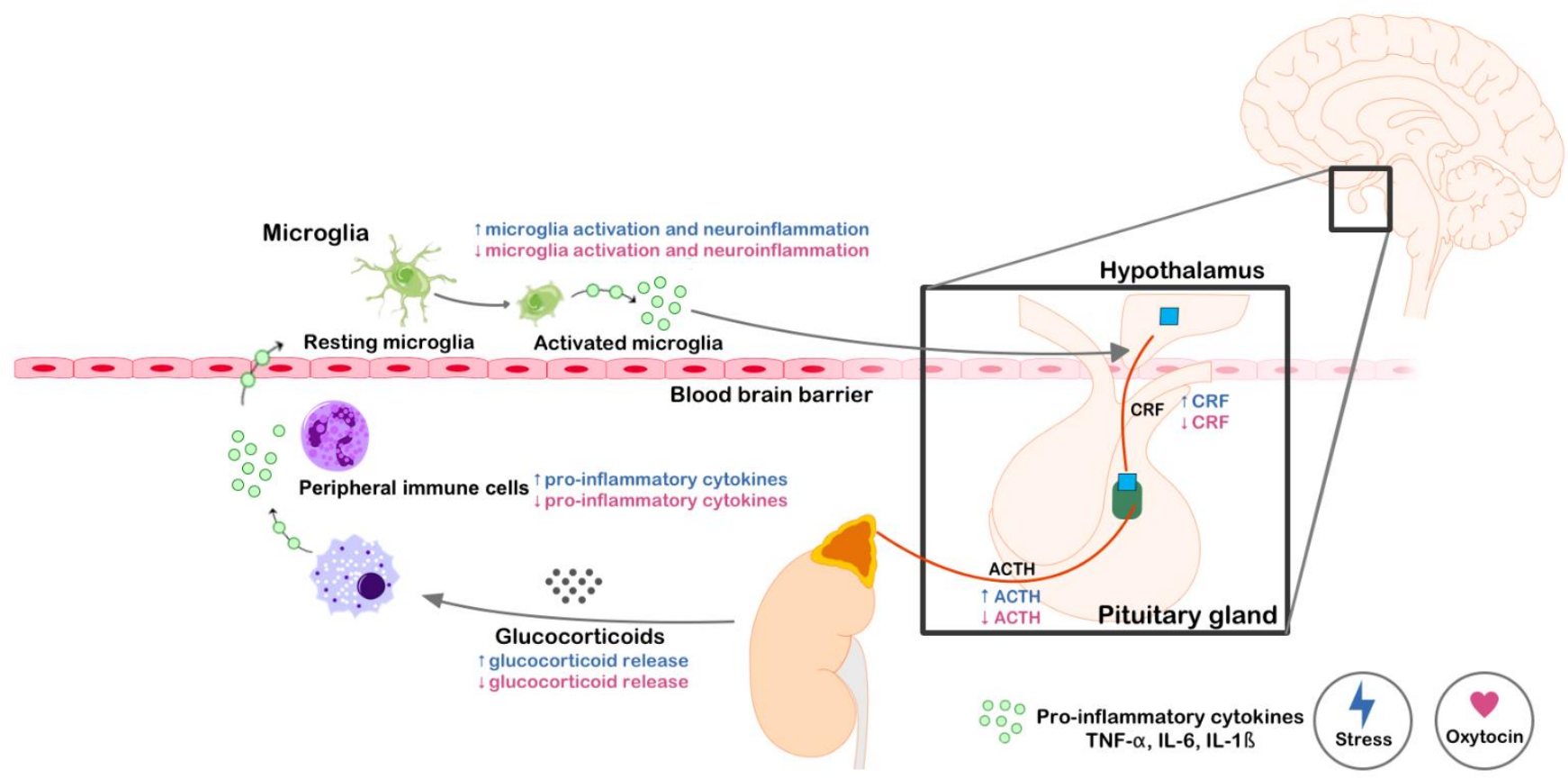

Figure 2. Oxytocin modulates the inflammatory response induced by stress. The effects of stress are depicted in blue, and those of oxytocin in pink. Stress activates the hypothalamic-pituitary-adrenal (HPA) axis and promotes the release of glucocorticoids that turn peripheral immune cells into a primed state. The activation of stress-primed immune cells can induce an exaggerated inflammatory response that eventually reaches the brain and promotes the activation of resident immune cells (neuroinflammation). Activated microglia within the brain release inflammatory cytokines that activate the HPA. Oxytocin counteracts the effects of stress in all the stages of this loop.

\section{Final Remarks}

The preclinical and clinical studies reviewed in this paper clearly supports the hypothesis that endogenous and exogenous OXT exerts a protective effect in all the stages of the addiction cycle by modulating the initial response to drugs and by attenuating the development of dependence. In this regard, the anti-stress potential of the neuropeptide is especially promising as it buffers against the negative impact of stress over drug-related behaviors.

However, the studies referred to in the present review have inherent limitations that are worth taking into consideration such as the existence of sexual differences in OXT dynamics, both in humans and animal models. Moreover, there are methodological differences between studies that can be summarized in the following aspects: (1) the paradigms used to provoke social stress vary among the different studies; (2) different methods of administering OXT-peripheral, intranasal, or intracerebral-have been used and will have undoubtedly exerted a different effect in each study; and (3) there is no unanimity 
with respect to the doses used in animal models. Bearing this in mind, we can affirm that the study of the role of OXT in social stress and the addictive process is at an early stage, but despite these limitations, it should continue based on the promising results obtained thus far.

This review sheds light on the importance of the role of the oxytocinergic system as a fundamental component in the understanding of substance use disorder. However, continuous drug use or chronic exposure to stress dysregulates this system. Exogenous OXT administration is a potentially interesting pharmacotherapy that allows the natural beneficial effects of OXT to be reaped and the balance in the functions of the stressed/addicted brain to be restored [192].

Author Contributions: Conceptualization, C.F.-P. and M.R.-A.; Methodology, C.F.-P. and M.D.R.; Software, C.F.-P. and M.D.R.; Validation, J.M. and M.R.-A.; Investigation, C.F.-P., M.D.R., and M.R.A.; Resources, J.M. and M.R.-A.; Writing-original draft preparation, C.F.-P., M.D.R., and M.R.-A.; Writing-review and editing, C.F.-P., M.D.R., and M.R.-A.; Project administration, J.M. and M.R.-A.; Funding acquisition, J.M. and M.R.-A. All authors have read and agreed to the published version of the manuscript.

Funding: This research was funded by Ministerio de Economía, Industria y Competitividad, Gobierno de España (MINECO), Dirección General de Investigación, PSI2017-83023-R; Instituto de Salud Carlos III, Red de Trastornos Adictivos (RTA; RETICS RD16/0017/0007) and Unión Europea, Fondos FEDER "A way to build Europe". M.D.R. received a FPI grant from the Spanish Ministry of Science, Innovation, and Universities (PRE2018-084159).

Institutional Review Board Statement: Not applicable.

Informed Consent Statement: Not applicable.

Data Availability Statement: Not applicable.

Acknowledgments: The authors would like to thank Brian Normanly for his help in editing the English language.

Conflicts of Interest: The authors declare no conflict of interest.

$\begin{array}{ll}\text { Abbreviations } \\ \text { ACTH } & \text { Adrenocorticotropic hormone } \\ \text { BNST } & \text { Bed nucleus of the stria terminalis } \\ \text { CBP } & \text { CREB-binding protein } \\ \text { CPP } & \text { Conditioned place preference } \\ \text { CREB } & \text { cAMP response element-binding protein } \\ \text { CRF } & \text { Corticotropin-releasing factor } \\ \text { DA } & \text { Dopamine } \\ \text { DARPP-32 } & \text { Dopamine and cAMP-regulated phosphoprotein of } 32 \mathrm{kDa} \\ \text { fMRI } & \text { Functional magnetic resonance imaging } \\ \text { GC } & \text { Glucocorticoids } \\ \text { HAT } & \text { Histone acetyltransferase } \\ \text { HDAC } & \text { Histone deacetylases } \\ \text { HPA } & \text { Hypothalamic-pituitary-adrenal } \\ \text { LS } & \text { Lateral septum } \\ \text { MDD } & \text { Major depression disorder } \\ \text { MeA } & \text { Medial amygdala } \\ \text { mPFC } & \text { Medial prefrontal cortex } \\ \text { NAc } & \text { Nucleus accumbens } \\ \text { OXT } & \text { Oxytocin } \\ \text { OXTR } & \text { Oxytocin receptor }\end{array}$




$\begin{array}{ll}\text { PFC } & \text { Prefrontal cortex } \\ \text { PKA } & \text { Protein kinase A } \\ \text { PVN } & \text { Paraventricular nucleus } \\ \text { SA } & \text { Self-administration } \\ \text { SD } & \text { Social defeat } \\ \text { SON } & \text { Supraoptic nucleus } \\ \text { VTA } & \text { Ventral tegmental area }\end{array}$

\section{References}

1. Jurek, B.; Neumann, I.D. The Oxytocin Receptor: From Intracellular Signaling to Behavior. Physiol. Rev. 2018, 98, 1805-1908. [CrossRef] [PubMed]

2. Gimpl, G.; Fahrenholz, F. The Oxytocin Receptor System: Structure, Function, and Regulation. Physiol. Rev. 2001, 81, 629-683. [CrossRef] [PubMed]

3. Dumais, K.M.; Veenema, A.H. Vasopressin and Oxytocin Receptor Systems in the Brain: Sex Differences and Sex-Specific Regulation of Social Behavior. Front. Neuroendocrinol. 2016, 40, 1-23. [CrossRef] [PubMed]

4. Quintana, D.S.; Guastella, A.J. An Allostatic Theory of Oxytocin. Trends Cogn. Sci. 2020, 24, 515-528. [CrossRef]

5. Lee, M.R.; Weerts, E.M. Oxytocin for the Treatment of Drug and Alcohol Use Disorders. Behav. Pharmacol. 2016, 27, 640-648. [CrossRef]

6. King, C.E.; Gano, A.; Becker, H.C. The Role of Oxytocin in Alcohol and Drug Abuse. Brain Res. 2020, 1736, 146761. [CrossRef]

7. Johns, J.M.; Caldwell, J.D.; Pedersen, C.A. Acute Cocaine Treatment Decreases Oxytocin Levels in the Rat Hippocampus. Neuropeptides 1993, 24, 165-169. [CrossRef]

8. Baracz, S.J.; Parker, L.M.; Suraev, A.S.; Everett, N.A.; Goodchild, A.K.; McGregor, I.S.; Cornish, J.L. Chronic Methamphetamine Self-Administration Dysregulates Oxytocin Plasma Levels and Oxytocin Receptor Fibre Density in the Nucleus Accumbens Core and Subthalamic Nucleus of the Rat. J. Neuroendocrinol. 2016, 28. [CrossRef]

9. Georgiou, P.; Zanos, P.; Hourani, S.; Kitchen, I.; Bailey, A. Cocaine Abstinence Induces Emotional Impairment and Brain Region-Specific Upregulation of the Oxytocin Receptor Binding. Eur. J. Neurosci. 2016, 44, 2446-2454. [CrossRef]

10. McGregor, I.S.; Callaghan, P.D.; Hunt, G.E. From Ultrasocial to Antisocial: A Role for Oxytocin in the Acute Reinforcing Effects and Long-Term Adverse Consequences of Drug Use? Br. J. Pharmacol. 2008, 154, 358-368. [CrossRef]

11. Clarke, G.; Wood, P.; Merrick, L.; Lincoln, D.W. Opiate Inhibition of Peptide Release from the Neurohumoral Terminals of Hypothalamic Neurones. Nature 1979, 282, 746-748. [CrossRef]

12. Kovács, G.L.; Laczi, F.; Vecsernyés, M.; Hódi, K.; Telegdy, G.; László, F.A. Limbic Oxytocin and Arginine 8-Vasopressin in Morphine Tolerance and Dependence. Exp. Brain Res. 1987, 65, 307-311. [CrossRef]

13. Zanos, P.; Georgiou, P.; Weber, C.; Robinson, F.; Kouimtsidis, C.; Niforooshan, R.; Bailey, A. Oxytocin and Opioid Addiction Revisited: Old Drug, New Applications. Br. J. Pharmacol. 2018, 175, 2809-2824. [CrossRef]

14. Zanos, P.; Georgiou, P.; Wright, S.R.; Hourani, S.M.; Kitchen, I.; Winsky-Sommerer, R.; Bailey, A. The Oxytocin Analogue Carbetocin Prevents Emotional Impairment and Stress-Induced Reinstatement of Opioid-Seeking in Morphine-Abstinent Mice. Neuropsychopharmacology 2014, 39, 855-865. [CrossRef] [PubMed]

15. Hansson, A.C.; Koopmann, A.; Uhrig, S.; Bühler, S.; Domi, E.; Kiessling, E.; Ciccocioppo, R.; Froemke, R.C.; Grinevich, V.; Kiefer, F.; et al. Oxytocin Reduces Alcohol Cue-Reactivity in Alcohol-Dependent Rats and Humans. Neuropsychopharmacology 2018, 43, 1235-1246. [CrossRef]

16. Butovsky, E.; Juknat, A.; Elbaz, J.; Shabat-Simon, M.; Eilam, R.; Zangen, A.; Altstein, M.; Vogel, Z. Chronic Exposure to Delta9Tetrahydrocannabinol Downregulates Oxytocin and Oxytocin-Associated Neurophysin in Specific Brain Areas. Mol. Cell. Neurosci. 2006, 31, 795-804. [CrossRef]

17. Mennella, J.A.; Pepino, M.Y.; Teff, K.L. Acute Alcohol Consumption Disrupts the Hormonal Milieu of Lactating Women. J. Clin. Endocrinol. Metab. 2005, 90, 1979-1985. [CrossRef] [PubMed]

18. Marchesi, C.; Chiodera, P.; Brusamonti, E.; Volpi, R.; Coiro, V. Abnormal Plasma Oxytocin and Beta-Endorphin Levels in Alcoholics after Short and Long Term Abstinence. Prog. Neuropsychopharmacol. Biol. Psychiatry 1997, 21, 797-807. [CrossRef]

19. Lee, M.R.; Schwandt, M.L.; Sankar, V.; Suchankova, P.; Sun, H.; Leggio, L. Effect of Alcohol Use Disorder on Oxytocin Peptide and Receptor MRNA Expression in Human Brain: A Post-Mortem Case-Control Study. Psychoneuroendocrinology 2017, 85, 14-19. [CrossRef] [PubMed]

20. Lee, M.R.; Rohn, M.C.H.; Tanda, G.; Leggio, L. Targeting the Oxytocin System to Treat Addictive Disorders: Rationale and Progress to Date. CNS Drugs 2016, 30, 109-123. [CrossRef]

21. Bowen, M.T.; Neumann, I.D. Rebalancing the Addicted Brain: Oxytocin Interference with the Neural Substrates of Addiction. Trends Neurosci. 2017, 40, 691-708. [CrossRef]

22. Koob, G.F.; Volkow, N.D. Neurobiology of Addiction: A Neurocircuitry Analysis. Lancet Psychiatry 2016, 3, 760-773. [CrossRef]

23. Dölen, G.; Darvishzadeh, A.; Huang, K.W.; Malenka, R.C. Social Reward Requires Coordinated Activity of Nucleus Accumbens Oxytocin and Serotonin. Nature 2013, 501, 179-184. [CrossRef] [PubMed]

24. Peris, J.; Steck, M.R.; Krause, E.G. Oxytocin Treatment for Alcoholism: Potential Neurocircuitry Targets. Neuropharmacology 2020, 171, 108091. [CrossRef] [PubMed] 
25. Peters, S.T.; Bowen, M.T.; Bohrer, K.; McGregor, I.S.; Neumann, I.D. Oxytocin Inhibits Ethanol Consumption and Ethanol-Induced Dopamine Release in the Nucleus Accumbens. Addict. Biol. 2017, 22, 702-711. [CrossRef] [PubMed]

26. Sarnyai, Z.; Szabó, G.; Kovács, G.L.; Telegdy, G. Oxytocin Attenuates the Cocaine-Induced Exploratory Hyperactivity in Mice. Neuroreport 1990, 1, 200-202. [CrossRef] [PubMed]

27. Carson, D.S.; Cornish, J.L.; Guastella, A.J.; Hunt, G.E.; McGregor, I.S. Oxytocin Decreases Methamphetamine Self-Administration, Methamphetamine Hyperactivity, and Relapse to Methamphetamine-Seeking Behaviour in Rats. Neuropharmacology 2010, 58, 38-43. [CrossRef]

28. Qi, J.; Yang, J.-Y.; Song, M.; Li, Y.; Wang, F.; Wu, C.-F. Inhibition by Oxytocin of Methamphetamine-Induced Hyperactivity Related to Dopamine Turnover in the Mesolimbic Region in Mice. Naunyn Schmiedebergs Arch. Pharmacol. 2008, 376, 441-448. [CrossRef]

29. Tops, M.; Koole, S.L.; IJzerman, H.; Buisman-Pijlman, F.T.A. Why Social Attachment and Oxytocin Protect against Addiction and Stress: Insights from the Dynamics between Ventral and Dorsal Corticostriatal Systems. Pharmacol. Biochem. Behav. 2014, 119, 39-48. [CrossRef]

30. El Rawas, R.; Amaral, I.M.; Hofer, A. Social Interaction Reward: A Resilience Approach to Overcome Vulnerability to Drugs of Abuse. Eur. Neuropsychopharmacol. 2020, 37, 12-28. [CrossRef]

31. Ballaz, S.J.; Akil, H.; Watson, S.J. Previous Experience Affects Subsequent Anxiety-like Responses in Rats Bred for Novelty Seeking. Behav. Neurosci. 2007, 121, 1113-1118. [CrossRef]

32. Arenas, M.C.; Aguilar, M.A.; Montagud-Romero, S.; Mateos-García, A.; Navarro-Francés, C.I.; Miñarro, J.; Rodríguez-Arias, M Influence of the Novelty-Seeking Endophenotype on the Rewarding Effects of Psychostimulant Drugs in Animal Models. Curr. Neuropharmacol. 2016, 14, 87-100. [CrossRef]

33. Dellu, F.; Piazza, P.V.; Mayo, W.; Le Moal, M.; Simon, H. Novelty-Seeking in Rats-Biobehavioral Characteristics and Possible Relationship with the Sensation-Seeking Trait in Man. Neuropsychobiology 1996, 34, 136-145. [CrossRef]

34. Qi, J.; Yang, J.-Y.; Wang, F.; Zhao, Y.-N.; Song, M.; Wu, C.-F. Effects of Oxytocin on Methamphetamine-Induced Conditioned Place Preference and the Possible Role of Glutamatergic Neurotransmission in the Medial Prefrontal Cortex of Mice in Reinstatement. Neuropharmacology 2009, 56, 856-865. [CrossRef]

35. Bowen, M.T.; Carson, D.S.; Spiro, A.; Arnold, J.C.; McGregor, I.S. Adolescent Oxytocin Exposure Causes Persistent Reductions in Anxiety and Alcohol Consumption and Enhances Sociability in Rats. PLoS ONE 2011, 6, e27237. [CrossRef] [PubMed]

36. Hicks, C.; Cornish, J.L.; Baracz, S.J.; Suraev, A.; McGregor, I.S. Adolescent Pre-Treatment with Oxytocin Protects against Adult Methamphetamine-Seeking Behavior in Female Rats. Addict. Biol. 2016, 21, 304-315. [CrossRef] [PubMed]

37. McGregor, I.S.; Bowen, M.T. Breaking the Loop: Oxytocin as a Potential Treatment for Drug Addiction. Horm. Behav. 2012, 61, 331-339. [CrossRef]

38. Venniro, M.; Zhang, M.; Caprioli, D.; Hoots, J.K.; Golden, S.A.; Heins, C.; Morales, M.; Epstein, D.H.; Shaham, Y. Volitional Social Interaction Prevents Drug Addiction in Rat Models. Nat. Neurosci. 2018, 21, 1520-1529. [CrossRef] [PubMed]

39. El Rawas, R.; Saria, A. The Two Faces of Social Interaction Reward in Animal Models of Drug Dependence. Neurochem. Res. 2016, 41, 492-499. [CrossRef] [PubMed]

40. Sampedro-Piquero, P.; Ávila-Gámiz, F.; Moreno Fernández, R.D.; Castilla-Ortega, E.; Santín, L.J. The Presence of a Social Stimulus Reduces Cocaine-Seeking in a Place Preference Conditioning Paradigm. J. Psychopharmacol. 2019, 33, 1501-1511. [CrossRef] [PubMed]

41. Pedersen, C.A. Oxytocin, Tolerance, and the Dark Side of Addiction. Int. Rev. Neurobiol. 2017, 136, 239-274. [CrossRef]

42. Kovács, G.L.; Horváth, Z.; Sarnyai, Z.; Faludi, M.; Telegdy, G. Oxytocin and a C-Terminal Derivative (Z-Prolyl-D-Leucine) Attenuate Tolerance to and Dependence on Morphine and Interact with Dopaminergic Neurotransmission in the Mouse Brain. Neuropharmacology 1985, 24, 413-419. [CrossRef]

43. Sarnyai, Z.; Viski, S.; Kriván, M.; Szabó, G.; Kovács, G.L.; Telegdy, G. Endogenous Oxytocin Inhibits Morphine Tolerance through Limbic Forebrain Oxytocin Receptors. Brain Res. 1988, 463, 284-288. [CrossRef]

44. Jodogne, C.; Tirelli, E.; Klingbiel, P.; Legros, J.J. Oxytocin Attenuates Tolerance Not Only to the Hypothermic but Also to the Myorelaxant and Akinesic Effects of Ethanol in Mice. Pharmacol. Biochem. Behav. 1991, 40, 261-265. [CrossRef]

45. Sarnyai, Z.; Babarczy, E.; Kriván, M.; Szabó, G.; Kovács, G.L.; Barth, T.; Telegdy, G. Selective Attenuation of Cocaine-Induced Stereotyped Behaviour by Oxytocin: Putative Role of Basal Forebrain Target Sites. Neuropeptides 1991, 19, 51-56. [CrossRef]

46. Sarnyai, Z.; Kovács, G.L. Oxytocin in Learning and Addiction: From Early Discoveries to the Present. Pharmacol. Biochem. Behav. 2014, 119, 3-9. [CrossRef]

47. Szabó, G.; Kovács, G.L.; Telegdy, G. Effects of Neurohypophyseal Peptide Hormones on Alcohol Dependence and Withdrawal. Alcohol Alcohol. 1987, 22, 71-74.

48. Pedersen, C.A.; Smedley, K.L.; Leserman, J.; Jarskog, L.F.; Rau, S.W.; Kampov-Polevoi, A.; Casey, R.L.; Fender, T.; Garbutt, J.C. Intranasal Oxytocin Blocks Alcohol Withdrawal in Human Subjects. Alcohol. Clin. Exp. Res. 2013, 37, 484-489. [CrossRef]

49. Stauffer, C.S.; Musinipally, V.; Suen, A.; Lynch, K.L.; Shapiro, B.; Woolley, J.D. A Two-Week Pilot Study of Intranasal Oxytocin for Cocaine-Dependent Individuals Receiving Methadone Maintenance Treatment for Opioid Use Disorder. Addict. Res. Theory 2016, 24, 490-498. [CrossRef] [PubMed]

50. Cox, B.M.; Young, A.B.; See, R.E.; Reichel, C.M. Sex Differences in Methamphetamine Seeking in Rats: Impact of Oxytocin. Psychoneuroendocrinology 2013, 38, 2343-2353. [CrossRef] [PubMed] 
51. Cox, B.M.; Bentzley, B.S.; Regen-Tuero, H.; See, R.E.; Reichel, C.M.; Aston-Jones, G. Oxytocin Acts in Nucleus Accumbens to Attenuate Methamphetamine Seeking and Demand. Biol. Psychiatry 2017, 81, 949-958. [CrossRef]

52. Miller, M.A.; Bershad, A.; King, A.C.; Lee, R.; de Wit, H. Intranasal Oxytocin Dampens Cue-Elicited Cigarette Craving in Daily Smokers: A Pilot Study. Behav. Pharmacol. 2016, 27, 697-703. [CrossRef]

53. McClure, E.A.; Baker, N.L.; Gray, K.M.; Hood, C.O.; Tomko, R.L.; Carpenter, M.J.; Ramakrishnan, V.R.; Buchanan, C.J.; Saladin, M.E. The Influence of Gender and Oxytocin on Stress Reactivity, Cigarette Craving, and Smoking in a Randomized, PlaceboControlled Laboratory Relapse Paradigm. Psychopharmacology 2020, 237, 543-555. [CrossRef]

54. Van Hedger, K.; Bershad, A.K.; Lee, R.; de Wit, H. Effects of Intranasal Oxytocin on Stress-Induced Cigarette Craving in Daily Smokers. Nicotine Tob. Res. 2020, 22, 89-95. [CrossRef]

55. McRae-Clark, A.L.; Baker, N.L.; Maria, M.M.-S.; Brady, K.T. Effect of Oxytocin on Craving and Stress Response in MarijuanaDependent Individuals: A Pilot Study. Psychopharmacology 2013, 228, 623-631. [CrossRef] [PubMed]

56. Reed, S.C.; Haney, M.; Manubay, J.; Campagna, B.R.; Reed, B.; Foltin, R.W.; Evans, S.M. Sex Differences in Stress Reactivity after Intranasal Oxytocin in Recreational Cannabis Users. Pharmacol. Biochem. Behav. 2019, 176, 72-82. [CrossRef] [PubMed]

57. Koob, G.F.; Schulkin, J. Addiction and Stress: An Allostatic View. Neurosci. Biobehav. Rev. 2019, 106, 245-262. [CrossRef]

58. Miller, A.H.; Haroon, E.; Felger, J.C. Therapeutic Implications of Brain-Immune Interactions: Treatment in Translation. Neuropsychopharmacology 2017, 42, 334-359. [CrossRef]

59. Ferrer-Pérez, C.; Castro-Zavala, A.; Luján, M.Á.; Filarowska, J.; Ballestín, R.; Miñarro, J.; Valverde, O.; Rodríguez-Arias, M. Oxytocin Prevents the Increase of Cocaine-Related Responses Produced by Social Defeat. Neuropharmacology 2019, 146, 50-64. [CrossRef] [PubMed]

60. Heinrichs, M.; Baumgartner, T.; Kirschbaum, C.; Ehlert, U. Social Support and Oxytocin Interact to Suppress Cortisol and Subjective Responses to Psychosocial Stress. Biol. Psychiatry 2003, 54, 1389-1398. [CrossRef]

61. Reguilón, M.D.; Ferrer-Pérez, C.; Miñarro, J.; Rodríguez-Arias, M. Oxytocin Reverses Ethanol Consumption and Neuroinflammation Induced by Social Defeat in Male Mice. Horm. Behav. 2021, 127, 104875. [CrossRef] [PubMed]

62. Selye, H. The evolution of the stress concept. Am. Sci. 1973, 61, 692-699. [CrossRef]

63. Chrousos, G.P. Stress and disorders of the stress system. Nat. Rev. Endocrinol. 2009, 5, 374-381. [CrossRef] [PubMed]

64. McEwen, B.S.; Wingfield, J.C. What is in a name? Integrating homeostasis, allostasis and stress. Horm. Behav. 2010, 57, 105-111. [CrossRef]

65. Panksepp, J. Neuroscience. Feeling the pain of social loss. Science 2003, 302, 237-239. [CrossRef]

66. Seidel, E.M.; Silani, G.; Metzler, H.; Thaler, H.; Lamm, C.; Gur, R.C.; Kryspin-Exner, I.; Habel, U.; Derntl, B. The impact of social exclusion vs. inclusion on subjective and hormonal reactions in females and males. Psychoneuroendocrinology 2013, 38, $2925-2932$. [CrossRef] [PubMed]

67. Tossani, E. The concept of mental pain. Psychother. Psychosom. 2013, 82, 67-73. [CrossRef]

68. Bains, J.S.; Wamsteeker Cusulin, J.I.; Inoue, W. Stress-related synaptic plasticity in the hypothalamus. Nat. Rev. Neurosci 2015, 16, 377-388. [CrossRef]

69. Neumann, I.D. Brain oxytocin: A key regulator of emotional and social behaviours in both females and males. J. Neuroendocrinol. 2008, 20, 858-865. [CrossRef] [PubMed]

70. Groves, N.J.; Zhou, M.; Jhaveri, D.J.; McGrath, J.J.; Burne, T. Adult vitamin D deficiency exacerbates impairments caused by social stress in BALB/c and C57BL/6 mice. Psychoneuroendocrinology 2017, 86, 53-63. [CrossRef]

71. Heshmati, M.; Christoffel, D.J.; LeClair, K.; Cathomas, F.; Golden, S.A.; Aleyasin, H.; Turecki, G.; Friedman, A.K.; Han, M.H.; Menard, C.; et al. Depression and Social Defeat Stress Are Associated with Inhibitory Synaptic Changes in the Nucleus Accumbens. J. Neurosci. 2020, 40, 6228-6233. [CrossRef]

72. Koo, J.W.; Chaudhury, D.; Han, M.H.; Nestler, E.J. Role of Mesolimbic Brain-Derived Neurotrophic Factor in Depression. Biol. Psychiatry 2019, 86, 738-748. [CrossRef] [PubMed]

73. Macedo, G.C.; Morita, G.M.; Domingues, L.P.; Favoretto, C.A.; Suchecki, D.; Quadros, I. Consequences of continuous social defeat stress on anxiety- and depressive-like behaviors and ethanol reward in mice. Horm. Behav. 2018, 97, 154-161. [CrossRef] [PubMed]

74. Niraula, A.; Wang, Y.; Godbout, J.P.; Sheridan, J.F. Corticosterone Production during Repeated Social Defeat Causes Monocyte Mobilization from the Bone Marrow, Glucocorticoid Resistance, and Neurovascular Adhesion Molecule Expression. J. Neurosci. 2018, 38, 2328-2340. [CrossRef]

75. Rodríguez-Arias, M.; Navarrete, F.; Blanco-Gandia, M.C.; Arenas, M.C.; Bartoll-Andrés, A.; Aguilar, M.A.; Rubio, G.; Miñarro, J.; Manzanares, J. Social defeat in adolescent mice increases vulnerability to alcohol consumption. Addict. Biol. 2016, 21, 87-97. [CrossRef]

76. Tas, C.; Brown, E.C.; Eskikurt, G.; Irmak, S.; Aydın, O.; Esen-Danaci, A.; Brüne, M. Cortisol response to stress in schizophrenia: Associations with oxytocin, social support and social functioning. Psychiatry Res. 2018, 270, 1047-1052. [CrossRef]

77. Selten, J.P.; van der Ven, E.; Rutten, B.P.; Cantor-Graae, E. The social defeat hypothesis of schizophrenia: An update. Schizophr. Bull. 2013, 39, 1180-1186. [CrossRef]

78. Tornatzky, W.; Miczek, K.A. Long-term impairment of autonomic circadian rhythms after brief intermittent social stress. Physiol. Behav. 1993, 53, 983-993. [CrossRef] 
79. Hammels, C.; Pishva, E.; De Vry, J.; van den Hove, D.L.; Prickaerts, J.; van Winkel, R.; Selten, J.P.; Lesch, K.P.; Daskalakis, N.P.; Steinbusch, H.W.; et al. Defeat stress in rodents: From behavior to molecules. Neurosci. Biobehav. Rev. 2015, 59, 111-140. [CrossRef] [PubMed]

80. Neisewander, J.L.; Peartree, N.A.; Pentkowski, N.S. Emotional valence and context of social influences on drug abuse-related behavior in animal models of social stress and prosocial interaction. Psychopharmacology 2012, 224, 33-56. [CrossRef]

81. Covington, H.E., 3rd; Miczek, K.A. Repeated social-defeat stress, cocaine or morphine. Effects on behavioral sensitization and intravenous cocaine self-administration "binges". Psychopharmacology 2001, 158, 388-398. [CrossRef] [PubMed]

82. Miczek, K.A.; Covington, H.E., 3rd; Nikulina, E.M., Jr.; Hammer, R.P. Aggression and defeat: Persistent effects on cocaine self-administration and gene expression in peptidergic and aminergic mesocorticolimbic circuits. Neurosci. Biobehav. Rev. 2004, 27, 787-802. [CrossRef]

83. Benton, D.; Brain, P.F. Behavioral and adrenocortical reactivity in female mice following individual or group housing. Dev. Psychobiol. 1981, 14, 101-107. [CrossRef] [PubMed]

84. Brown, K.J.; Grunberg, N.E. Effects of housing on male and female rats: Crowding stresses male but calm females. Physiol. Behav. 1995, 58, 1085-1089. [CrossRef]

85. Sial, O.K.; Warren, B.L.; Alcantara, L.F.; Parise, E.M.; Bolaños-Guzmán, C.A. Vicarious social defeat stress: Bridging the gap between physical and emotional stress. J. Neurosci. Methods 2016, 258, 94-103. [CrossRef]

86. Yohn, C.N.; Ashamalla, S.A.; Bokka, L.; Gergues, M.M.; Garino, A.; Samuels, B.A. Social instability is an effective chronic stress paradigm for both male and female mice. Neuropharmacology 2019, 160, 107780. [CrossRef]

87. Bao, A.M.; Meynen, G.; Swaab, D.F. The stress system in depression and neurodegeneration: Focus on the human hypothalamus. Brain Res. Rev. 2008, 57, 531-553. [CrossRef]

88. Leistner, C.; Menke, A. Hypothalamic-pituitary-adrenal axis and stress. Handb. Clin. Neurol. 2020, 175, 55-64. [CrossRef]

89. Lupien, S.J.; Maheu, F.; Tu, M.; Fiocco, A.; Schramek, T.E. The effects of stress and stress hormones on human cognition: Implications for the field of brain and cognition. Brain Cogn. 2007, 65, 209-237. [CrossRef]

90. Smeets, T. Autonomic and hypothalamic-pituitary-adrenal stress resilience: Impact of cardiac vagal tone. Biol. Psychol. 2010, 84, 290-295. [CrossRef]

91. Bhattacharyya, S.; Ratajczak, C.K.; Vogt, S.K.; Kelley, C.; Colonna, M.; Schreiber, R.D.; Muglia, L.J. TAK1 targeting by glucocorticoids determines JNK and IkappaB regulation in Toll-like receptor-stimulated macrophages. Blood 2010, 115, $1921-1931$. [CrossRef]

92. Grad, I.; Picard, D. The glucocorticoid responses are shaped by molecular chaperones. Mol. Cell. Endocrinol. 2007, $275,2-12$. [CrossRef]

93. Kagoshima, M.; Ito, K.; Cosio, B.; Adcock, I.M. Glucocorticoid suppression of nuclear factor-kappa B: A role for histone modifications. Biochem. Soc. Trans. 2003, 31, 60-65. [CrossRef]

94. Leung, D.Y.; Bloom, J.W. Update on glucocorticoid action and resistance. J. Allergy Clin. Immunol. 2003, 111, 3-23. [CrossRef] [PubMed]

95. Stahn, C.; Buttgereit, F. Genomic and nongenomic effects of glucocorticoids. Nat. Clin. Pract. Rheumatol. 2008, 4, 525-533. [CrossRef] [PubMed]

96. Busillo, J.M.; Cidlowski, J.A. The five Rs of glucocorticoid action during inflammation: Ready, reinforce, repress, resolve, and restore. Trends Endocrinol. Metab. 2013, 24, 109-119. [CrossRef]

97. Webster, J.C.; Oakley, R.H.; Jewell, C.M.; Cidlowski, J.A. Proinflammatory cytokines regulate human glucocorticoid receptor gene expression and lead to the accumulation of the dominant negative beta isoform: A mechanism for the generation of glucocorticoid resistance. Proc. Natl. Acad. Sci. USA 2001, 98, 6865-6870. [CrossRef]

98. Jeanneteau, F.D.; Lambert, W.M.; Ismaili, N.; Bath, K.G.; Lee, F.S.; Garabedian, M.J.; Chao, M.V. BDNF and glucocorticoids regulate corticotrophin-releasing hormone (CRH) homeostasis in the hypothalamus. Proc. Natl. Acad. Sci. USA 2012, 109, 1305-1310. [CrossRef]

99. Logrip, M.L.; Koob, G.F.; Zorrilla, E.P. Role of corticotropin-releasing factor in drug addiction: Potential for pharmacological intervention. CNS Drugs 2011, 25, 271-287. [CrossRef] [PubMed]

100. Francis, T.C.; Chandra, R.; Friend, D.M.; Finkel, E.; Dayrit, G.; Miranda, J.; Brooks, J.M.; Iñiguez, S.D.; O’Donnell, P.; Kravitz, A.; et al. Nucleus accumbens medium spiny neuron subtypes mediate depression-related outcomes to social defeat stress. Biol. Psychiatry 2015, 77, 212-222. [CrossRef] [PubMed]

101. Heshmati, M.; Russo, S.J. Anhedonia and the brain reward circuitry in depression. Curr. Behav. Neurosci. Rep. 2015, 2, 146-153. [CrossRef] [PubMed]

102. Finnell, J.E.; Moffitt, C.M.; Hesser, L.A.; Harrington, E.; Melson, M.N.; Wood, C.S.; Wood, S.K. The contribution of the locus coeruleus-norepinephrine system in the emergence of defeat-induced inflammatory priming. Brain Behav. Immun. 2019, 79, 102-113. [CrossRef] [PubMed]

103. Haenisch, B.; Bilkei-Gorzo, A.; Caron, M.G.; Bönisch, H. Knockout of the norepinephrine transporter and pharmacologically diverse antidepressants prevent behavioral and brain neurotrophin alterations in two chronic stress models of depression. J. Neurochem. 2009, 111, 403-416. [CrossRef] [PubMed] 
104. Hasegawa, S.; Miyake, Y.; Yoshimi, A.; Mouri, A.; Hida, H.; Yamada, K.; Ozaki, N.; Nabeshima, T.; Noda, Y. Dysfunction of Serotonergic and Dopaminergic Neuronal Systems in the Antidepressant-Resistant Impairment of Social Behaviors Induced by Social Defeat Stress Exposure as Juveniles. Int. J. Neuropsychopharmacol. 2018, 21, 837-846. [CrossRef]

105. Ramírez, L.A.; Pérez-Padilla, E.A.; García-Oscos, F.; Salgado, H.; Atzori, M.; Pineda, J.C. A new theory of depression based on the serotonin/kynurenine relationship and the hypothalamicpituitary-adrenal axis. Biomedica 2018, 38, 437-450. [CrossRef] [PubMed]

106. Cooper, M.A.; Grober, M.S.; Nicholas, C.R.; Huhman, K.L. Aggressive encounters alter the activation of serotonergic neurons and the expression of 5-HT1A mRNA in the hamster dorsal raphe nucleus. Neuroscience 2009, 161, 680-690. [CrossRef] [PubMed]

107. Zhang, J.; Fan, Y.; Li, Y.; Zhu, H.; Wang, L.; Zhu, M.Y. Chronic social defeat up-regulates expression of the serotonin transporter in rat dorsal raphe nucleus and projection regions in a glucocorticoid-dependent manner. J. Neurochem. 2012, 123, 1054-1068 [CrossRef]

108. Tanaka, M.; Yoshida, M.; Emoto, H.; Ishii, H. Noradrenaline systems in the hypothalamus, amygdala and locus coeruleus are involved in the provocation of anxiety: Basic studies. Eur. J. Pharmacol. 2000, 405, 397-406. [CrossRef]

109. Cohen, S.; Janicki-Deverts, D.; Doyle, W.J.; Miller, G.E.; Frank, E.; Rabin, B.S.; Turner, R.B. Chronic stress, glucocorticoid receptor resistance, inflammation, and disease risk. Proc. Natl. Acad. Sci. USA 2012, 109, 5995-5999. [CrossRef]

110. Horowitz, M.A.; Cattaneo, A.; Cattane, N.; Lopizzo, N.; Tojo, L.; Bakunina, N.; Musaelyan, K.; Borsini, A.; Zunszain, P.A.; Pariante, C.M. Glucocorticoids prime the inflammatory response of human hippocampal cells through up-regulation of inflammatory pathways. Brain Behav. Immun. 2020, 87, 777-794. [CrossRef]

111. Johnson, J.D.; Barnard, D.F.; Kulp, A.C.; Mehta, D.M. Neuroendocrine Regulation of Brain Cytokines After Psychological Stress. J. Endocr. Soc. 2019, 3, 1302-1320. [CrossRef]

112. Takahashi, A.; Flanigan, M.E.; McEwen, B.S.; Russo, S.J. Aggression, Social Stress, and the Immune System in Humans and Animal Models. Front. Behav. Neurosci. 2018, 12, 56. [CrossRef]

113. Zhu, L.J.; Ni, H.Y.; Chen, R.; Chang, L.; Shi, H.J.; Qiu, D.; Zhang, Z.; Wu, D.L.; Jiang, Z.C.; Xin, H.L.; et al. Hippocampal nuclear factor kappa B accounts for stress-induced anxiety behaviors via enhancing neuronal nitric oxide synthase (nNOS)-carboxyterminal PDZ ligand of nNOS-Dexras1 coupling. J. Neurochem. 2018, 146, 598-612. [CrossRef] [PubMed]

114. Wang, S.C.; Lin, C.C.; Tzeng, N.S.; Tung, C.S.; Liu, Y.P. Effects of oxytocin on prosocial behavior and the associated profiles of oxytocinergic and corticotropin-releasing hormone receptors in a rodent model of posttraumatic stress disorder. J. Biomed. Sci. 2019, 26, 26. [CrossRef]

115. Winter, J.; Jurek, B. The interplay between oxytocin and the CRF system: Regulation of the stress response. Cell Tissue Res. 2019, 375, 85-91. [CrossRef] [PubMed]

116. Jurek, B.; Slattery, D.A.; Hiraoka, Y.; Liu, Y.; Nishimori, K.; Aguilera, G.; Neumann, I.D.; van den Burg, E.H. Oxytocin Regulates Stress-Induced Crf Gene Transcription through CREB-Regulated Transcription Coactivator 3. J. Neurosci. 2015, 35, 12248-12260. [CrossRef] [PubMed]

117. Gobrogge, K.; Wang, Z. Neuropeptidergic regulation of pair-bonding and stress buffering: Lessons from voles. Horm. Behav. 2015, 76, 91-105. [CrossRef]

118. Gunnar, M.R.; Hostinar, C.E. The social buffering of the hypothalamic-pituitary-adrenocortical axis in humans: Developmental and experiential determinants. Soc. Neurosci. 2015, 10, 479-488. [CrossRef] [PubMed]

119. Heck, A.L.; Sheng, J.A.; Miller, A.M.; Stover, S.A.; Bales, N.J.; Tan, S.; Daniels, R.M.; Fleury, T.K.; Handa, R.J. Social isolation alters hypothalamic pituitary adrenal axis activity after chronic variable stress in male C57BL/6 mice. Stress 2020, 23, 457-465. [CrossRef] [PubMed]

120. Engelmann, M.; Landgraf, R.; Wotjak, C.T. The hypothalamic-neurohypophysial system regulates the hypothalamic-pituitaryadrenal axis under stress: An old concept revisited. Front. Neuroendocrinol. 2004, 25, 132-149. [CrossRef]

121. Neumann, I.D.; Landgraf, R. Balance of brain oxytocin and vasopressin: Implications for anxiety, depression, and social behaviors. Trends Neurosci. 2012, 35, 649-659. [CrossRef] [PubMed]

122. Quirin, M.; Kuhl, J.; Düsing, R. Oxytocin buffers cortisol responses to stress in individuals with impaired emotion regulation abilities. Psychoneuroendocrinology 2011, 36, 898-904. [CrossRef] [PubMed]

123. Smith, A.S.; Wang, Z. Hypothalamic oxytocin mediates social buffering of the stress response. Biol. Psychiatry 2014, 76, 281-288. [CrossRef]

124. Engert, V.; Koester, A.M.; Riepenhausen, A.; Singer, T. Boosting recovery rather than buffering reactivity: Higher stress-induced oxytocin secretion is associated with increased cortisol reactivity and faster vagal recovery after acute psychosocial stress. Psychoneuroendocrinology 2016, 74, 111-120. [CrossRef] [PubMed]

125. Brown, C.A.; Cardoso, C.; Ellenbogen, M.A. A meta-analytic review of the correlation between peripheral oxytocin and cortisol concentrations. Front. Neuroendocrinol. 2016, 43, 19-27. [CrossRef]

126. Jong, T.R.; Menon, R.; Bludau, A.; Grund, T.; Biermeier, V.; Klampfl, S.M.; Jurek, B.; Bosch, O.J.; Hellhammer, J.; Neumann, I.D. Salivary oxytocin concentrations in response to running, sexual self-stimulation, breastfeeding and the TSST: The Regensburg Oxytocin Challenge (ROC) study. Psychoneuroendocrinology 2015, 62, 381-388. [CrossRef]

127. Litvin, Y.; Murakami, G.; Pfaff, D.W. Effects of chronic social defeat on behavioral and neural correlates of sociality: Vasopressin, oxytocin and the vasopressinergic V1b receptor. Physiol Behav. 2011, 103, 393-403. [CrossRef] [PubMed]

128. Nasanbuyan, N.; Yoshida, M.; Takayanagi, Y.; Inutsuka, A.; Nishimori, K.; Yamanaka, A.; Onaka, T. Oxytocin-Oxytocin Receptor Systems Facilitate Social Defeat Posture in Male Mice. Endocrinology 2018, 159, 763-775. [CrossRef] 
129. Steinman, M.Q.; Duque-Wilckens, N.; Greenberg, G.D.; Hao, R.; Campi, K.L.; Laredo, S.A.; Laman-Maharg, A.; Manning, C.E.; Doig, I.E.; Lopez, E.M.; et al. Sex-Specific Effects of Stress on Oxytocin Neurons Correspond With Responses to Intranasal Oxytocin. Biol. Psychiatry 2016, 80, 406-414. [CrossRef]

130. Steinman, M.Q.; Laredo, S.A.; Lopez, E.M.; Manning, C.E.; Hao, R.C.; Doig, I.E.; Campi, K.L.; Flowers, A.E.; Knight, J.K.; Trainor, B.C. Hypothalamic vasopressin systems are more sensitive to the long term effects of social defeat in males versus females. Psychoneuroendocrinology 2015, 51, 122-134. [CrossRef]

131. Duque-Wilckens, N.; Steinman, M.Q.; Busnelli, M.; Chini, B.; Yokoyama, S.; Pham, M.; Laredo, S.A.; Hao, R.; Perkeybile, A.M.; Minie, V.A.; et al. Oxytocin Receptors in the Anteromedial Bed Nucleus of the Stria Terminalis Promote Stress-Induced Social Avoidance in Female California Mice. Biol. Psychiatry 2018, 83, 203-213. [CrossRef]

132. Nowacka-Chmielewska, M.M.; Kasprowska-Liśkiewicz, D.; Barski, J.J.; Obuchowicz, E.; Małecki, A. The behavioral and molecular evaluation of effects of social instability stress as a model of stress-related disorders in adult female rats. Stress 2017, 20, 549-561. [CrossRef]

133. Hou, W.; He, Z.; Yang, Y.; Yuan, W.; Wang, L.; Zhang, J.; Zhang, X.; Cai, W.; Guo, Q.; Tai, F. The involvement of oxytocin in the effects of chronic social defeat stress on emotional behaviours in adult female mandarin voles. Eur. J. Neurosci. 2020, 52, 2853-2872. [CrossRef]

134. Yuen, K.W.; Garner, J.P.; Carson, D.S.; Keller, J.; Lembke, A.; Hyde, S.A.; Kenna, H.A.; Tennakoon, L.; Schatzberg, A.F.; Parker, K.J. Plasma oxytocin concentrations are lower in depressed vs. healthy control women and are independent of cortisol. J. Psychiatr. Res. 2014, 51, 30-36. [CrossRef]

135. Jobst, A.; Sabass, L.; Palagyi, A.; Bauriedl-Schmidt, C.; Mauer, M.C.; Sarubin, N.; Buchheim, A.; Renneberg, B.; Falkai, P.; Zill, P.; et al. Effects of social exclusion on emotions and oxytocin and cortisol levels in patients with chronic depression. J. Psychiatr. Res. 2015, 60, 170-177. [CrossRef]

136. Eckstein, M.; Scheele, D.; Weber, K.; Stoffel-Wagner, B.; Maier, W.; Hurlemann, R. Oxytocin facilitates the sensation of social stress. Hum. Brain Mapp. 2014, 35, 4741-4750. [CrossRef]

137. Yoon, S.; Kim, Y.K. The Role of the Oxytocin System in Anxiety Disorders. Adv. Exp. Med. Biol. 2020, 1191, 103-120. [CrossRef] [PubMed]

138. Hoge, E.A.; Lawson, E.A.; Metcalf, C.A.; Keshaviah, A.; Zak, P.J.; Pollack, M.H.; Simon, N.M. Plasma oxytocin immunoreactive products and response to trust in patients with social anxiety disorder. Depress. Anxiety 2012, 29, 924-930. [CrossRef] [PubMed]

139. Dodhia, S.; Hosanagar, A.; Fitzgerald, D.A.; Labuschagne, I.; Wood, A.G.; Nathan, P.J.; Phan, K.L. Modulation of resting-state amygdala-frontal functional connectivity by oxytocin in generalized social anxiety disorder. Neuropsychopharmacology 2014, 39, 2061-2069. [CrossRef] [PubMed]

140. Labuschagne, I.; Phan, K.L.; Wood, A.; Angstadt, M.; Chua, P.; Heinrichs, M.; Stout, J.C.; Nathan, P.J. Oxytocin attenuates amygdala reactivity to fear in generalized social anxiety disorder. Neuropsychopharmacology 2010, 35, 2403-2413. [CrossRef]

141. Labuschagne, I.; Phan, K.L.; Wood, A.; Angstadt, M.; Chua, P.; Heinrichs, M.; Stout, J.C.; Nathan, P.J. Medial frontal hyperactivity to sad faces in generalized social anxiety disorder and modulation by oxytocin. Int. J. Neuropsychopharmacol. 2012, 15, 883-896. [CrossRef]

142. Luo, L.; Becker, B.; Geng, Y.; Zhao, Z.; Gao, S.; Zhao, W.; Yao, S.; Zheng, X.; Ma, X.; Gao, Z.; et al. Sex-dependent neural effect of oxytocin during subliminal processing of negative emotion faces. Neuroimage 2017, 162, 127-137. [CrossRef]

143. Fang, A.; Treadway, M.T.; Hofmann, S.G. Working hard for oneself or others: Effects of oxytocin on reward motivation in social anxiety disorder. Biol. Psychol. 2017, 127, 157-162. [CrossRef]

144. Fan, Y.; Herrera-Melendez, A.L.; Pestke, K.; Feeser, M.; Aust, S.; Otte, C.; Pruessner, J.C.; Böker, H.; Bajbouj, M.; Grimm, S. Early life stress modulates amygdala-prefrontal functional connectivity: Implications for oxytocin effects. Hum. Brain Mapp. 2014, 35, 5328-5339. [CrossRef] [PubMed]

145. Feeser, M.; Fan, Y.; Weigand, A.; Hahn, A.; Gärtner, M.; Aust, S.; Böker, H.; Bajbouj, M.; Grimm, S. The beneficial effect of oxytocin on avoidance-related facial emotion recognition depends on early life stress experience. Psychopharmacology 2014, 231, 4735-4744. [CrossRef] [PubMed]

146. Schwaiger, M.; Heinrichs, M.; Kumsta, R. Oxytocin administration and emotion recognition abilities in adults with a history of childhood adversity. Psychoneuroendocrinology 2019, 99, 66-71. [CrossRef] [PubMed]

147. Nawijn, L.; van Zuiden, M.; Koch, S.B.; Frijling, J.L.; Veltman, D.J.; Olff, M. Intranasal oxytocin enhances neural processing of monetary reward and loss in post-traumatic stress disorder and traumatized controls. Psychoneuroendocrinology 2016, 66, $228-237$. [CrossRef] [PubMed]

148. Nawijn, L.; van Zuiden, M.; Koch, S.B.; Frijling, J.L.; Veltman, D.J.; Olff, M. Intranasal oxytocin increases neural responses to social reward in post-traumatic stress disorder. Soc. Cogn. Affect. Neurosci. 2017, 12, 212-223. [CrossRef] [PubMed]

149. Koch, S.B.; van Zuiden, M.; Nawijn, L.; Frijling, J.L.; Veltman, D.J.; Olff, M. Intranasal Oxytocin Normalizes Amygdala Functional Connectivity in Posttraumatic Stress Disorder. Neuropsychopharmacology 2016, 41, 2041-2051. [CrossRef]

150. Koch, S.; van Zuiden, M.; Nawijn, L.; Frijling, J.L.; Veltman, D.J.; Olff, M. Effects of intranasal oxytocin on distraction as emotion regulation strategy in patients with post-traumatic stress disorder. Eur. Neuropsychopharmacol. 2019, 29, 266-277. [CrossRef]

151. Wang, L.; Hou, W.; He, Z.; Yuan, W.; Yang, J.; Yang, Y.; Jia, R.; Zhu, Z.; Zhou, Y.; Tai, F. Effects of chronic social defeat on social behaviors in adult female mandarin voles (Microtus mandarinus): Involvement of the oxytocin system in the nucleus accumbens. Prog. Neuropsychopharmacol. Biol. Psychiatry 2018, 82, 278-288. [CrossRef] 
152. Li, Q.; Zhang, B.; Cao, H.; Liu, W.; Guo, F.; Shen, F.; Ye, B.; Liu, H.; Li, Y.; Liu, Z. Oxytocin Exerts Antidepressant-like effect by potentiating dopaminergic synaptic transmission in the mPFC. Neuropharmacology 2020, 162, 107836. [CrossRef]

153. Arena, D.T.; Covington, H.E., 3rd; DeBold, J.F.; Miczek, K.A. Persistent increase of I.V. cocaine self-administration in a subgroup of C57BL/6J male mice after social defeat stress. Psychopharmacology 2019, 236, 2027-2037. [CrossRef] [PubMed]

154. Boyson, C.O.; Holly, E.N.; Shimamoto, A.; Albrechet-Souza, L.; Weiner, L.A.; DeBold, J.F.; Miczek, K.A. Social stress and CRFdopamine interactions in the VTA: Role in long-term escalation of cocaine self-administration. J. Neurosci. 2014, 34, 6659-6667. [CrossRef] [PubMed]

155. Han, X.; DeBold, J.F.; Miczek, K.A. Prevention and reversal of social stress-escalated cocaine self-administration in mice by intra-VTA CRFR1 antagonism. Psychopharmacology 2017, 234, 2813-2821. [CrossRef] [PubMed]

156. Leonard, M.Z.; DeBold, J.F.; Miczek, K.A. Escalated cocaine "binges" in rats: Enduring effects of social defeat stress or intra-VTA CRF. Psychopharmacology 2017, 234, 2823-2836. [CrossRef] [PubMed]

157. Montagud-Romero, S.; Reguilón, M.D.; Pascual, M.; Blanco-Gandía, M.C.; Guerri, C.; Miñarro, J.; Rodríguez-Arias, M. Critical role of TLR4 in uncovering the increased rewarding effects of cocaine and ethanol induced by social defeat in male mice. Neuropharmacology 2021, 182, 108368. [CrossRef]

158. Reguilón, M.D.; Ferrer-Pérez, C.; Ballestín, R.; Miñarro, J.; Rodríguez-Arias, M. Voluntary wheel running protects against the increase in ethanol consumption induced by social stress in mice. Drug Alcohol Depend. 2020, 212, 108004. [CrossRef]

159. Ballestín, R.; Alegre-Zurano, L.; Ferrer-Pérez, C.; Cantacorps, L.; Miñarro, J.; Valverde, O.; Rodríguez-Arias, M. Neuroinflammatory and behavioral susceptibility profile of mice exposed to social stress towards cocaine effects. Prog. Neuropsychopharmacol. Biol. Psychiatry 2021, 105, 110123. [CrossRef]

160. Ferrer-Pérez, C.; Reguilón, M.D.; Manzanedo, C.; Aguilar, M.A.; Miñarro, J.; Rodríguez-Arias, M. Antagonism of corticotropinreleasing factor CRF1 receptors blocks the enhanced response to cocaine after social stress. Eur. J. Pharmacol. 2018, 823, 87-95. [CrossRef] [PubMed]

161. Montagud-Romero, S.; Nuñez, C.; Blanco-Gandia, M.C.; Martínez-Laorden, E.; Aguilar, M.A.; Navarro-Zaragoza, J.; Almela, P.; Milanés, M.V.; Laorden, M.L.; Miñarro, J.; et al. Repeated social defeat and the rewarding effects of cocaine in adult and adolescent mice: Dopamine transcription factors, proBDNF signaling pathways, and the TrkB receptor in the mesolimbic system. Psychopharmacology 2017, 234, 2063-2075. [CrossRef] [PubMed]

162. Aguilar, M.A.; Rodríguez-Arias, M.; Miñarro, J. Neurobiological mechanisms of the reinstatement of drug-conditioned place preference. Brain Res. Rev. 2009, 59, 253-277. [CrossRef] [PubMed]

163. Tzschentke, T.M. Measuring reward with the conditioned place preference (CPP) paradigm: Update of the last decade. Addict. Biol. 2007, 12, 227-462. [CrossRef] [PubMed]

164. Miczek, K.A.; Yap, J.J.; Covington, H.E., 3rd. Social stress, therapeutics and drug abuse: Preclinical models of escalated and depressed intake. Pharmacol. Ther. 2008, 120, 102-128. [CrossRef]

165. Vasconcelos, M.; Stein, D.J.; de Almeida, R.M. Social defeat protocol and relevant biomarkers, implications for stress response physiology, drug abuse, mood disorders and individual stress vulnerability: A systematic review of the last decade. Trends Psychiatry Psychother. 2015, 37, 51-66. [CrossRef]

166. Holly, E.N.; DeBold, J.F.; Miczek, K.A. Increased mesocorticolimbic dopamine during acute and repeated social defeat stress: Modulation by corticotropin releasing factor receptors in the ventral tegmental area. Psychopharmacology 2015, 232, 4469-4479. [CrossRef]

167. Hwa, L.S.; Holly, E.N.; DeBold, J.F.; Miczek, K.A. Social stress-escalated intermittent alcohol drinking: Modulation by CRF-R1 in the ventral tegmental area and accumbal dopamine in mice. Psychopharmacology 2016, 233, 681-690. [CrossRef] [PubMed]

168. Yap, J.J.; Chartoff, E.H.; Holly, E.N.; Potter, D.N.; Carlezon, W.A., Jr.; Miczek, K.A. Social defeat stress-induced sensitization and escalated cocaine self-administration: The role of ERK signaling in the rat ventral tegmental area. Psychopharmacology 2015, 232, 1555-1569. [CrossRef] [PubMed]

169. Matsushita, H.; Latt, H.M.; Koga, Y.; Nishiki, T.; Matsui, H. Oxytocin and Stress: Neural Mechanisms, Stress-Related Disorders, and Therapeutic Approaches. Neuroscience 2019, 417, 1-10. [CrossRef]

170. Lee, H.; Jang, M.; Noh, J. Oxytocin attenuates aversive response to nicotine and anxiety-like behavior in adolescent rats. Neurosci. Res. 2017, 115, 29-36. [CrossRef] [PubMed]

171. Hung, L.W.; Neuner, S.; Polepalli, J.S.; Beier, K.T.; Wright, M.; Walsh, J.J.; Lewis, E.M.; Luo, L.; Deisseroth, K.; Dölen, G.; et al. Gating of social reward by oxytocin in the ventral tegmental area. Science 2017, 357, 1406-1411. [CrossRef]

172. Peris, J.; MacFadyen, K.; Smith, J.A.; de Kloet, A.D.; Wang, L.; Krause, E.G. Oxytocin receptors are expressed on dopamine and glutamate neurons in the mouse ventral tegmental area that project to nucleus accumbens and other mesolimbic targets. J. Comp. Neurol. 2017, 525, 1094-1108. [CrossRef]

173. Xiao, L.; Priest, M.F.; Nasenbeny, J.; Lu, T.; Kozorovitskiy, Y. Biased Oxytocinergic Modulation of Midbrain Dopamine Systems. Neuron 2017, 95, 368-384.e5. [CrossRef]

174. Ferrer-Pérez, C.; Reguilón, M.D.; Manzanedo, C.; Miñarro, J.; Rodríguez-Arias, M. Social Housing Conditions Modulate the Long-Lasting Increase in Cocaine Reward Induced by Intermittent Social Defeat. Front. Behav. Neurosci. 2019, 13, 148. [CrossRef]

175. Ferrer-Pérez, C.; Reguilón, M.D.; Miñarro, J.; Rodríguez-Arias, M. Endogenous oxytocin is essential for the buffering effects of pair housing against the increase in cocaine reward induced by social stress. Physiol. Behav. 2020, 221, 112913. [CrossRef] [PubMed] 
176. King, C.E.; Becker, H.C. Oxytocin attenuates stress-induced reinstatement of alcohol seeking behavior in male and female mice. Psychopharmacology 2019, 236, 2613-2622. [CrossRef] [PubMed]

177. Ferland, C.L.; Reichel, C.M.; McGinty, J.F. Effects of oxytocin on methamphetamine-seeking exacerbated by predator odor pre-exposure in rats. Psychopharmacology 2016, 233, 1015-1024. [CrossRef]

178. Flanagan, J.C.; Baker, N.L.; McRae-Clark, A.L.; Brady, K.T.; Moran-Santa Maria, M.M. Effects of adverse childhood experiences on the association between intranasal oxytocin and social stress reactivity among individuals with cocaine dependence. Psychiatry Res. 2015, 229, 94-100. [CrossRef] [PubMed]

179. Flanagan, J.C.; Allan, N.P.; Calhoun, C.D.; Badour, C.L.; Moran-Santa Maria, M.; Brady, K.T.; Back, S.E. Effects of oxytocin on stress reactivity and craving in veterans with co-occurring PTSD and alcohol use disorder. Exp. Clin. Psychopharmacol. 2019, 27, 45-54. [CrossRef] [PubMed]

180. Hood, C.O.; Tomko, R.L.; Baker, N.L.; Tuck, B.M.; Flanagan, J.C.; Carpenter, M.J.; Gray, K.M.; Saladin, M.E.; McClure, E.A. Examining sex, adverse childhood experiences, and oxytocin on neuroendocrine reactivity in smokers. Psychoneuroendocrinology 2020, 120, 104752. [CrossRef]

181. Calcia, M.A.; Bonsall, D.R.; Bloomfield, P.S.; Selvaraj, S.; Barichello, T.; Howes, O.D. Stress and neuroinflammation: A systematic review of the effects of stress on microglia and the implications for mental illness. Psychopharmacology 2016, 233, 1637-1650. [CrossRef]

182. Montagud-Romero, S.; Blanco-Gandía, M.C.; Reguilón, M.D.; Ferrer-Pérez, C.; Ballestín, R.; Miñarro, J.; Rodríguez-Arias, M. Social defeat stress: Mechanisms underlying the increase in rewarding effects of drugs of abuse. Eur. J. Neurosci. 2018, 48, 2948-2970. [CrossRef] [PubMed]

183. Rodríguez-Arias, M.; Montagud-Romero, S.; Rubio-Araiz, A.; Aguilar, M.A.; Martín-García, E.; Cabrera, R.; Maldonado, R.; Porcu, F.; Colado, M.I.; Miñarro, J. Effects of repeated social defeat on adolescent mice on cocaine-induced CPP and self-administration in adulthood: Integrity of the blood-brain barrier. Addict. Biol. 2017, 22, 129-141. [CrossRef] [PubMed]

184. Weber, M.D.; Godbout, J.P.; Sheridan, J.F. Repeated Social Defeat, Neuroinflammation, and Behavior: Monocytes Carry the Signal. Neuropsychopharmacology 2017, 42, 46-61. [CrossRef] [PubMed]

185. Stankiewicz, A.M.; Goscik, J.; Majewska, A.; Swiergiel, A.H.; Juszczak, G.R. The Effect of Acute and Chronic Social Stress on the Hippocampal Transcriptome in Mice. PLoS ONE 2015, 10, e0142195. [CrossRef]

186. Ferrer-Pérez, C.; Escrivá-Martinez, T.; Montagud-Romero, S.; Ballestín, R.; Reguilón, M.D.; Miñarro, J.; Rodríguez-Arias, M. Indomethacin blocks the increased conditioned rewarding effects of cocaine induced by repeated social defeat. PLoS ONE 2019, 14, e0212397. [CrossRef]

187. Akman, T.; Akman, L.; Erbas, O.; Terek, M.C.; Taskiran, D.; Ozsaran, A. The preventive effect of oxytocin to Cisplatin-induced neurotoxicity: An experimental rat model. Biomed. Res. Int. 2015, 167235. [CrossRef]

188. Karelina, K.; Stuller, K.A.; Jarrett, B.; Zhang, N.; Wells, J.; Norman, G.J.; DeVries, A.C. Oxytocin mediates social neuroprotection after cerebral ischemia. Stroke 2011, 42, 3606-3611. [CrossRef]

189. Yuan, L.; Liu, S.; Bai, X.; Gao, Y.; Liu, G.; Wang, X.; Liu, D.; Li, T.; Hao, A.; Wang, Z. Oxytocin inhibits lipopolysaccharide-induced inflammation in microglial cells and attenuates microglial activation in lipopolysaccharide-treated mice. J. Neuroinflamm. 2016, 13, 77. [CrossRef]

190. Amini-Khoei, H.; Mohammadi-Asl, A.; Amiri, S.; Hosseini, M.J.; Momeny, M.; Hassanipour, M.; Rastegar, M.; Haj-Mirzaian, A.; Mirzaian, A.H.; Sanjarimoghaddam, H.; et al. Oxytocin mitigated the depressive-like behaviors of maternal separation stress through modulating mitochondrial function and neuroinflammation. Prog. Neuropsychopharmacol. Biol. Psychiatry 2017, 76, 169-178. [CrossRef]

191. Wang, S.C.; Lin, C.C.; Chen, C.C.; Tzeng, N.S.; Liu, Y.P. Effects of Oxytocin on Fear Memory and Neuroinflammation in a Rodent Model of Posttraumatic Stress Disorder. Int. J. Mol. Sci. 2018, 19, 3848. [CrossRef] [PubMed]

192. Baracz, S.J.; Everett, N.A.; Cornish, J.L. The impact of early life stress on the central oxytocin system and susceptibility for drug addiction: Applicability of oxytocin as a pharmacotherapy. Neurosci. Biobehav. Rev. 2020, 110, 114-132. [CrossRef] [PubMed] 